\title{
The Mechanical, Stress- Rupture, and Fracture \\ Toughness Properties of \\ Normalized and Stress \\ Relieved AAR TC128 \\ Grade B Steel at Elevated \\ Temperatures
}

George E. Hicho

U.S. DEPARTMENT OF COMMERCE Technology Administration

National Institute of Standards

and Technology

Gaithersburg, MD 20899

QC

100

.456

NLT 


\section{The Mechanical, Stress- \\ Rupture, and Fracture \\ Toughness Properties of \\ Normalized and Stress \\ Relieved AAR TC128 \\ Grade B Steel at Elevated \\ Temperatures}

George E. Hicho

U.S. DEPARTMENT OF COMMERCE Technology Administration

National Institute of Standards and Technology

Gaithersburg, MD 20899

March 1993

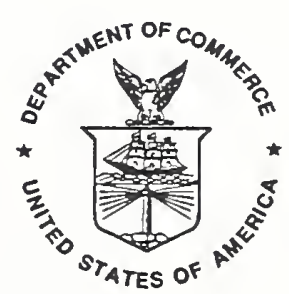

U.S. DEPARTMENT OF COMMERCE Ronald H. Brown, Secretary

NATIONAL INSTITUTE OF STANDARDS AND TECHNOLOGY

Raymond G. Kammer, Acting Director 
THE MECHANICAL, STRESS-RUPTURE, AND FRACTURE TOUGHNESS PROPERTIES

OF NORMALIZED AND STRESS RELIEVED

AAR TC128 GRADE B STEEL AT

ELEVATED TEMPERATURES

George E. Hicho

\begin{abstract}
Mechanical Properties and Performance Group
Materials Science and Engineering Laboratory

National Institute of Standards and Technology

Metallurgy Division

Gaithersburg, MD 20899
\end{abstract}

\title{
ABSTRACT
}

The mechanical, fracture toughness, and stress-rupture properties of a normalized and stress relieved tank car steel were found to be reduced by increased temperature and time at temperature. The effects of loading rates, 0.0127 and $0.127 \mathrm{~cm} / \mathrm{min}$, on these properties were also evaluated. Most affected was the yield strength, where at the loading rate of $0.127 \mathrm{~cm} / \mathrm{min}$, the yield strength as a function of temperature and time at temperature was greater than that obtained under similar test conditions at a loading rate of $0.0127 \mathrm{~cm} / \mathrm{min}$. The ultimate and yield strength were observed to decrease continuously from $593{ }^{\circ} \mathrm{C}$ to $677{ }^{\circ} \mathrm{C}$ for time of 60,90 , and 120 minutes. The ductility, in terms of the elongation and reduction-of-area were found to increase over these same test temperatures and times. The fracture toughness, because of the yield strength decrease as the temperature increased, decreased as the test temperature increased. Fracture toughness tests found the steel to be highly resistant to unstable fracture, and stress-rupture tests revealed that the rupture lifetime could be extended, at elevated temepratures, by reducing the maximum internal pressure of the tank car.

\section{INTRODUCTION}

As of January 1989, the Federal Railroad Administration (FRA) requires new tank cars that carry hazardous commodities be constructed of normalized AAR TCl28 grade $B$ steel and that the tank car be stress relieved after fabrication. In order to develop a database for the steel in this condition, the Mechanical Properties and Performance Group (MPPG) of the National Institute of Standards and Technology (NIST) was asked by the FRA to determine the steel's mechanical and fracture toughness properties from room temperature to the lowest temperature the steel could possibly encounter while in use in North America. This research $(1,2)$ detailing the steel's mechanical, fracture toughness, and crack arrest properties from room temperature to $-51{ }^{\circ} \mathrm{C}\left(-60^{\circ} \mathrm{F}\right)$ showed that the steel had 
acceptable tensile properties, i.e., yield, ultimate etc., but more importantly, the impact properties at low test temperatures were better than those obtained for as-rolled AAR TC128 grade B steel. The fracture toughness test results, for similar test temperatures, indicated that the normalized and stress relieved steel was more resistant to crack initiation and was better able to arrest a propagating crack than as-rolled or normalized AAR TC128 grade B steel.

Having determined the mechanical and fracture properties of the normalized and stress relieved steel from room temperature to $-51{ }^{\circ} \mathrm{C}$, the question arose as to how this steel, now in a tank car, responded once it was exposed to fire. Results obtained from previous investigations ( $3,4,5)$ revealed that fire temperatures at accident sites ranged from about $593^{\circ} \mathrm{C}$ ( $1100{ }^{\circ} \mathrm{F}$ ) to about $677^{\circ} \mathrm{C}\left(1250^{\circ} \mathrm{F}\right)$. These same reports indicated that once a tank car was engulfed in fire - - with the absence of a cooling environment but venting its contents via a relief valve - - it would probably explode in about 90 minutes. Over the years, as a result of research conducted by both the railroad industry and the federal government on tank cars, steps have been taken to reduce the chances of catastrophic tank car failures that were so prevalent during the $1970 \mathrm{~s}(6,7)$. Current research $(1,2,8,9)$ has shown that the steel now required for new tank cars, normalized and stress relieved AAR TC128 grade B steel, in the absence of a fire, is more resistant to catastrophic failure at low temperatures compared to as-rolled AAR TCl28 grade B steel. The question yet unanswered was, "What are the mechanical, stress-rupture, and fracture toughness properties of the steel when subjected to a fire?" The MPPG group at NIST was requested to conduct experiments and prepare a report that detailed the mechanical, stress-rupture, and fracture toughness properties of normalized and stress relieved AAR TCl28 grade $B$ steel at temperatures and times similar to those encountered in a fire.

\section{TEST MATERIAL}

Four plates, each $1.4 \mathrm{~cm}(9 / 16$ inch) in thickness by $183 \mathrm{~cm}$ (72 inch) square were made for the test program by Bethlehem Steel Corporation according to Association of American Railroads (AAR) specification M128 for grade B flange quality steel. The plates were purchased from the Bethlehem Steel Corporation, through Union Tank Car Company (UTC), with the help of Mr. Thomas Dalrymple, Chief Engineer of UTC. Appendix I shows Bethlehem Steel's test and analysis report with the chemistry and metallurgical particulars included, and that the plates were normalized after rolling. (Normalizing is a heat treatment that produces a uniform microstructure in a steel plate, which leads to improved mechanical and fracture properties).

\section{TEST PROGRAM}

\section{Stress Relieving, As-received Microstructure, and Chemistry:}

Prior to sectioning the tast specimens from the plate "J", the as-rolled and normalized plate was stress zelieved according to AAR specifications by the Union Tank Company. The stress relieving (recovery anneal) was done at $649{ }^{\circ} \mathrm{C}$ $\left(1200^{\circ} \mathrm{F}\right.$ ) for one hour, and photomicrographs were taken of the normalized and stress relieved plate in the un tched and etched conditions. For check purposes, the chemical composition of the as rolled plate was determined. 
Uniformly sized test coupons, used to determine the affects of temperature and time on the microstructure of this steel, and hence its mechanical properties, were prepared and heated to 593, 621, 649, and $677{ }^{\circ} \mathrm{C}$ for $30,60,90$, and 120 minutes, respectively. Photomicrographs were taken to determine the affects of temperature and time on the steel. Hardness measurements were also taken to examine the affects of time, temperature, or a combination of both on the hardness.

\section{Hot-Tensile Program:}

Standard American Society for Testing and Materials (ASTM) tensile specimens with a reduced diameter of $6.4 \mathrm{~mm}$ ( $0.250 \mathrm{inch}$ ) were prepared from the $1 / 4$ thickness position in the plate according to ASTM Method A 370-90. The test specimens were taken from the ASTM L-T (long axis of specimen parallel to the rolling direction of the plate) and the ASTM T-L (long axis of the specimen perpendicular to the rolling direction of the plate) directions. The specimens were tested at 593, 621,649 , and $677^{\circ} \mathrm{C}$ for $30,60,90$, and 120 minutes, respectively, at crosshead speeds of $0.0127 \mathrm{~cm} / \mathrm{min}(0.005 \mathrm{inch} / \mathrm{min})$ and $0.127 \mathrm{~cm} / \mathrm{min}(0.05 \mathrm{inch} / \mathrm{min})$ to determine the effects of time, temperature, and strain rate. The specimens were tested in an environmental chamber with no protective atmosphere. After yielding, the crosshead speed was increased to $0.127 \mathrm{~cm} / \mathrm{min}$ for those specimens that were initially loaded at $0.0127 \mathrm{~cm} / \mathrm{min}$. The crosshead speed of $0.127 \mathrm{~cm} / \mathrm{min}$ was maintained throughout the test for appropriate specimens. Chart and crosshead speed, and machine compliance were used to estimate the $0.2 \%$ offset yield strength. The elongation to failure was obtained by measuring the distance between fiduciary marks, placed $2.54 \mathrm{~cm}$ apart, after testing.

\section{Stress-Rupture Program:}

Standard ASTM tensile specimens, identical to those described above, were tested in accordance with ASTM Method E 21-79, Elevated Temperature Tension Tests of Metallic Materials to determine the stress-rupture properties. The yield strength values obtained from the hot-tensile test results were used to set the test loads for the stress-rupture tests. Each specimen was placed in the test chamber and a minor load applied. The furnace power was activated and the specimen was allowed to reach the predetermined test temperature - - 593, 621, 649, or $677^{\circ} \mathrm{C}$. After 15 minutes at temperature (time estimated for a plate $1.4 \mathrm{~cm}$ in thickness to reach temperature), the load corresponding to the desired yield strength was applied to the system, and the timer activated. Specimen extension was measured by gages located outside the test chamber, and recorded as a function of time. At specimen rupture, the time was recorded. From these results - applied stress, time to failure, and temperature, a family of curves showing stress-rupture as a function of temperature were developed.

\section{Fracture Toughness Program:}

Fracture toughness specimens were prepared and tested according to ASTM Method E 813-89, Standard Test Method for $J_{I C}$, a Measure of Fracture Toughness. Specimens were heated in an environmental chamber at the temperatures of 593, 621,649 , and $677^{\circ} \mathrm{C}$. Initially a specimen was heated to $677^{\circ} \mathrm{C}$ for 120 minutes 
and tested. The test results indicated that it was virtually impossible to initiate or propagate a crack and hence, a shorter test time, 90 minutes was selected to evaluate the fracture toughness of the steel. The specimens were tested in the ASTM T-L and T-L directions. As with the hot-tensile specimens, chart speed, crosshead speed, and machine compliance were used to estimate the maximum load applied to a specimen at the onset of crack propagation. This load was used to calculate the fracture toughness.

\section{RESULTS}

\section{Chemistry:}

Table 1 shows the AAR specification to which the steel was melted, the heat check analyses as determined by the Bethlehem Steel Corporation, and the NIST check analyses. The results showed that steel was within acceptable limits and made according to the specification. Although the chromium content was 0.01 weight percent over that allowed, it was within the ASTM chemical error limits established for that element. Included in the chemical analyses results is the carbon equivalent, $C E$. The carbon equivalent is helpful to the metallurgist and welder in determining the susceptibility of the weld to heat affected zone cracking. The higher the $C E$, the higher the probability for such to occur if such practices as pre- and post-weld procedures are not stringently observed. (Other factors such as the size of the pieces welded should be considered in determining weld cracking susceptibility).

\section{Grain Size Determinations:}

ASTM Method E 112-88, Standard Test Method for Determining Grain Size, was used to determine the proeutectoid ferrite/pearlite grain size of the normalized and stress-relieved steel. The grain size was determined at the $1 / 4$ thickness location, and at two distant locations in a coupon. The grain size for one area was $6.6 \mu \mathrm{m}$ which corresponds to ASTM number 11.2 ; and $6.4 \mu \mathrm{m}$, ASTM number 11.3 , for another area. Both grain-size numbers indicate the steel was made to fine grain practice.

\section{Microstructural Observations:}

The steel's microstructural response to temperature and time were determined. Unetched and etched specimens were examined. In the unetched condition, that is, no acid applied to the steel to reveal its microstructure, the "cleanliness" of the steel, in terms of the area percent of inclusions present, was measured optically. Figure 1 shows photomicrographs of the steel in the unetched condition and in three orthogonal directions. This shows that: 1) on the surface inclusions are "pancake" in appearance, 2) parallel to the rolling direction, inclusions are elongated, and 3) into the rolling direction, inclusions are "dots" in the photomicrograph. The elongated manganese sulfide inclusions (dark lines in the figure) reveal the primary rolling direction of the plate. Sulfides, in particular the manganese sulfide type that lie between the proeutectoid ferrite/pearlite interfaces in the steel, are paths of low resistance and promote both crack initiation and propagation. Using the ASTM metallographic standard for the determination of inclusion content of steels, the cleanliness of plate "J," as revealed by the overall inclusion content of the specimen, was 
found to be low compared with other steels. Normalized plate "J" was therefore classified as a "clean" steel and was found, as a result in previous work by the author (2), to have both improved impact and fracture toughness properties compared to as-rolled steel.

Figure 2 shows photomicrographs of the as-received normalized steel in the etched condition in three orthogonal directions. In the normalizing treatment, the steel is heated to $899^{\circ} \mathrm{C}\left(1650{ }^{\circ} \mathrm{F}\right)$, held at that temperature for 30 minutes and then air cooled to room temperature. This heat treatment essentially "normalizes" the microstructure, that is the proeutectoid ferrite and pearlite (the light and dark constituents in the photomicrograph) become equiaxed in size -. an indication that grain growth has occurred, and the deformation was diminished. AAR TCl28 grade B steel is normally used in the as-rolled condition. In that condition, the proeutectoid ferrite and pearlite are "pancaked" in appearance. In the rolling of the plate, both the proeutectoid ferrite and pearlite are severely deformed, and as a result the mechanical properties (9), in particular the impact strengths, are less than those measured for a normalized steel. In the same photomicrograph of the etched steel, the proeutectoid ferrite/pearlite is observed to exist in layers, that is, there is a layer of proeutectoid ferrite then a layer of pearlite repeated throughout the specimen. This layering metallurgically is called "banding," and is due primarily to chemical segregation in the ingot during metallurgical processing and cannot be removed by any heat treatment other than remelting the steel. The "banding" affect is more pronounced in the as-rolled steel than in the normalized steel, due to the deformation given to the steel in processing. Normalizing, an added expense, is performed after the rolling to reduce the deformation of the proeutectoid ferrite and pearlite by allowing grain growth of the proeutectoid ferrite and pearlite to occur. Normalizing does not relieve the deformation completely or the banding, but does metallurgically produces changes in the proeutectoid ferrite, and especially in the pearlite, that result in significant improvements in both the mechanical and impact properties of the steel.

Figure 3 shows the microstructure in two locations in the steel after stress relieving. Figures 4 through 11 show the microstructures of the normalized and stress relieved coupons after they were heat treated at 593, 621, 649, and $677^{\circ} \mathrm{C}$ for $30,60,90$, and 120 minute intervals. The photomicrographs show that there was a gradual increase in the size of both the pearlite and proeutectoid ferrite as the time at temperature and temperature increased. After 30 or 60 minutes and $593{ }^{\circ} \mathrm{C}$, figures $4 \mathrm{a}$ and $4 \mathrm{~b}$, the resultant microstructures were similar to those observed for the normalized and stress-relieved material. The most significant change in microstructure occurred when the steel was treated at $677^{\circ} \mathrm{C}$ for 90 and 120 minutes. At those temperatures and times, the photomicrographs (figures $1 \mathrm{la}$ and $1 \mathrm{lb}$ ) show that the proeutectoid ferrite grains (light constituent) have grown in size. In addition, the $\mathrm{Fe}_{3} \mathrm{C}$ (iron carbide) - dark spheroid particles around and within the pearlite - was observed to have coarsened. Coarsening of the pearlite, which could lead to softening of the steel, was also revealed by hardness determinations.

\section{Hardness:}

Table 2 shows the hardness results and figure 12 is a plot of these results. The figure affirms the microstructure indications, that is, irrespective of the 
temperature and time - at $593{ }^{\circ} \mathrm{C}$ to $649{ }^{\circ} \mathrm{C}$, and for 30,60 , or 90 minutes - the hardness did not change dramatically. Only at $677{ }^{\circ} \mathrm{C}$, and after 60 , 90 , or 120 minutes at temperature, was hardness reduced. Albeit the reduction in hardness was minimal, about one Rockwell A unit, this difference will be evidenced in the mechanical property results to be presented later.

\section{Tensile Properties:}

(At room temperature to $-51^{\circ} \mathrm{C}$ )

For comparison purposes the ultimate tensile strength (UTS) and $0.2 \%$ offset yield strength (YS) results, determined in a previous work (2) for this same steel at temperatures ranging from $22{ }^{\circ} \mathrm{C}$ to $-51{ }^{\circ} \mathrm{C}$, are shown in figure 13 . The UTS at temperatures from $22{ }^{\circ} \mathrm{C}$ to $-51{ }^{\circ} \mathrm{C}$ ranged from about $620 \mathrm{MPa}$ (90 ksi) to $695 \mathrm{MPa}$ (101 ksi) for the L-T specimens, and $558 \mathrm{MPa}$ ( $81 \mathrm{ksi}$ ) to $606 \mathrm{MPa}$ (88 ksi) for the specimens tested in the T-L direction. The YS at these same temperature ranged from $427 \mathrm{MPa}(62 \mathrm{ksi}$ ) to $558 \mathrm{MPa}$ (72 ksi) for the L-T specimens, and $393 \mathrm{MPa}$ (57 ksi) to $427 \mathrm{MPa}(65 \mathrm{ksi})$ for the specimens tested in the T-L direction. The UTS and YS for specimens taken from the ASTM L-T direction in the test plate were greater than those for specimens taken in the ASTM T-L direction. This difference in mechanical properties could be due to either inclusion content and orientation, or the deformation given to the proeutectoid ferrite/pearlite microstructure during the rolling process. Since the steel was given a normalizing heat treatment after rolling, resulting in a uniform proeutectoid ferrite/ pearlite grain size in both $\mathrm{L}-\mathrm{T}$ and $\mathrm{T}-\mathrm{L}$ directions, inclusion content and orientation played the predominant roles in the steel's mechanical properties. Figure 1 shows the unetched steel three orthogonal directions, and the extent of inclusions in the steel. For tensile specimens taken in the T-L direction, that is the primary inclusions lie in planes normal to the long axis of the test specimen, less energy is needed to cause rupture of the tensile specimen. For specimens tested in the L-T direction, where the primary inclusions are aligned parallel to the long axis of the tensile specimen, more more energy, compared to the $\mathrm{T}-\mathrm{L}$ specimens, is needed to cause rupture of the specimen.

\section{Tensile Properties:}

(Affects of exposure time at elevated temperature)

The UTS and YS were determined for specimens taken from the T-L and L-T directions, at temperatures of 593, 621, 649, and $677{ }^{\circ} \mathrm{C}$ for exposure times of 60, 90, and 120 minutes. Two different crosshead speeds were used to determine the affects of strain rate on the mechanical properties. Tables 3, 4, 5, and 6 show the UTS and YS, the percent elongation in $25.4 \mathrm{~mm}$, and the percent reduction of area. The UTS and YS results at each temperature, at crosshead speeds of 0.0127 and $0.127 \mathrm{~cm} / \mathrm{min}$, are plotted as a function of exposure time in figures $14,15,16$, and 17 .

Figure 14, for test specimens taken from the L-T direction and strained at 0.0127 $\mathrm{cm} / \mathrm{min}$, shows that both the UTS and YS were essentially uniform over the test temperatures, regardless whether the exposure time was 60 , 90, or 120 minutes. However, in the same figure, is the difference between the UTS and YS values as a function of exposure time and time at temperature. Over the test temperatures and time the difference between the UTS and YS, on the average, was about $36 \%$. 
As expected due to the change in microstructure of the steel revealed in the metallographic examinations, a difference between the room temperature (see figure 13) and the elevated temperature tensile properties was observed. The room temperature UTS and YS were $620 \mathrm{MPa}(90 \mathrm{ksi}$ ) and $427 \mathrm{MPa}$ (62 ksi), respectively.

Similar tensile tests were conducted on specimens taken from the same L-T direction, but pulled at a crosshead speed of $0.127 \mathrm{~cm} / \mathrm{minute}$. Figure 15 shows these test results. After 60,90 , or 120 minutes exposure at $677{ }^{\circ} \mathrm{C}$, both the UTS and YS were essentially uniform--the UTS was $123 \mathrm{MPa}$ (18 ksi) and the YS 105 $\mathrm{MPa}$ ( $15 \mathrm{ksi}$ ), a difference of $15 \%$ compared to $36 \%$ for specimens tested at the slower crosshead speed of $0.0127 \mathrm{~cm} / \mathrm{min}$. At $593^{\circ} \mathrm{C}$ the difference between the UTS and YS was $27 \%$; at $621{ }^{\circ} \mathrm{C}, 23 \%$; and at $649{ }^{\circ} \mathrm{C}, 17 \%$. The affects of the increased crosshead speed, i.e., material work hardening, is shown by the decrease in the difference between the UTS and YS values, or the YS approaching the UTS value.

The differences between the room temperature and elevated temperature UTS results were consistent with those obtained at the crosshead speed of $0.0127 \mathrm{~cm} / \mathrm{min}$. However, the difference between the room and elevated temperature YS results was less, due to the increased crosshead speed of $0.127 \mathrm{~cm} /$ minute. The difference between the room temperature and $593{ }^{\circ} \mathrm{C}$ UTS and YS values were $61 \%$ and $59 \%$, respectively; at $621{ }^{\circ} \mathrm{C}, 69 \%$ and $65 \%$; at $649{ }^{\circ} \mathrm{C}, 74 \%$ and $64 \%$; and at $677{ }^{\circ} \mathrm{C}, 80 \%$ and $75 \%$. Increasing the crosshead speed to $0.127 \mathrm{~cm} / \mathrm{minute}$ from $0.0127 \mathrm{~cm} / \mathrm{minute}$ a did not affect the UTS results over the test temperatures, but did affect the YS results.

Figure 16 shows the UTS and YS results for specimens taken in the T-L direction, tested at 593, 621, 649, and $677^{\circ} \mathrm{C}$ after exposure for 60, 90, or 120 minutes. The specimens were tested at a crosshead speed of $0.0127 \mathrm{~cm} / \mathrm{minute}$, and the figure shows that both the UTS and YS, over the test temperatures, were uniform over the range of exposure times. Differences between the UTS and YS were determined and it was found that at all test temperatures, the difference between the UTS and YS was about $36.5 \%$ similar to that found for the T-L specimens tested at the crosshead speed of $0.0127 \mathrm{~cm} / \mathrm{minute}$.

Comparison of the room temperature and elevated temperature data for these same specimens revealed that the difference between these values increased as the test temperature increased. At $593{ }^{\circ} \mathrm{C}$, the difference in UTS values was $60 \%$ and $64 \%$ for the YS; at $621{ }^{\circ} \mathrm{C}, 69 \%$ and $70 \%$; at $649{ }^{\circ} \mathrm{C}, 75 \%$ and $76 \%$; and at $677{ }^{\circ} \mathrm{C}, 80 \%$ and $82 \%$. Figure 17 shows that the UTS and YS results for T-L specimens tested at a crosshead speed of $0.127 \mathrm{~cm} /$ minute were essentially uniform for the test temperatures and exposure times used. The differences, on the average, between the UTS and YS were less, approximately $22 \%$, than those measured at the higher crosshead speed. A comparison of the room temperature and elevated temperature UTS and YS results showed that the same trend observed for the UTS and YS results for the T-L specimens was found for the L-T specimens tested at the higher crosshead speed. At $593{ }^{\circ} \mathrm{C}$ the difference between the UTS and YS was $60 \%$ for the UTS and $57 \%$ for the YS; at $621{ }^{\circ} \mathrm{C}, 68 \%$ and $65 \%$; at $649{ }^{\circ} \mathrm{C}, 75 \%$ and $71 \%$, and at $677{ }^{\circ} \mathrm{C}, 80 \%$ and $76 \%$.

Figures 18 and 19 show the affects of exposure time, temperature and crosshead speed on the UTS. Figure 18, specimens taken from the L-T direction, showed that 
the effect of crosshead speed, i.e., difference in UTS, was not as pronounced at the test temperatures of 593,621 , or $649{ }^{\circ} \mathrm{C}$. Only at $677^{\circ} \mathrm{C}$ was the difference evident. Similarly as shown in figure 19, for specimens taken from the $\mathrm{T}-\mathrm{I}$ direction, the difference between the UTS obtained using different crosshead speeds appears to be minimal, even at $677^{\circ} \mathrm{C}$. Figures 20 and 21 show Ys results for similar test conditions. For both the L-T and T-L specimens, the effects of crosshead speed are more pronounced. The overall Effect of increased crosshead speed is to increase the YS regardless of test temperature or time at temperature.

\section{Tensile Properties:}

\section{(Effects of temperature)}

Figures 22, 23, 24, and 25, plots of UTS and YS versus temperature, show that there was a continuous decrease in these values as the test temperature and time at temperature increased. Not shown in these figures, but in Tables 3, 4, 6, and 6 , was that there was also a continuous increase in the percent elongation as the test temperature increased from $593^{\circ} \mathrm{C}$ to $677{ }^{\circ} \mathrm{C}$. The reduction-in-area was found to be not as sensitive to temperature as the elongation. The reduction-inarea increased, as the test temperature increased, but not to the extent the elongation increased. In figure 22, for specimens taken from the $T$-I direction and tested at a crosshead speed of $0.0127 \mathrm{~cm} /$ minute, the UTS was $240 \mathrm{MPa}$ at $593{ }^{\circ} \mathrm{C}$ and $125 \mathrm{MPa}$ at $677{ }^{\circ} \mathrm{C}$. The YS also decreased from $150 \mathrm{MPa}$ at $593{ }^{\circ} \mathrm{C}$ to $76 \mathrm{MPa}$ at $677^{\circ} \mathrm{C}$. The affect of increasing the crosshead speed to $0.127 \mathrm{~cm} /$ minute on the UTS and YS in the T-L direction is shown in figure 23 . The UTS decreased from $240 \mathrm{MPa}$ at $593^{\circ} \mathrm{C}$ to $126 \mathrm{MPa}$ at $677{ }^{\circ} \mathrm{C}$, and the YS decreased from $175 \mathrm{MPa}$ at $593{ }^{\circ} \mathrm{C}$ to $110 \mathrm{MPa}$ at $677^{\circ} \mathrm{C}$. Conversely, the elongation and reduction-in-area were found to increase as the test temperature increased. The yield-to-ultimate strength ratio $(\mathrm{Y} / \mathrm{T})$ at the higher crosshead speed was much greater $(0.80)$ than that at the lower crosshead speed $(0.60)$ due to the fact that yield strength is more rate sensitive than ultimate tensile strength. The $Y / T$ ratio, however, was not affected by temperature or time at temperature. Regardless of the time or temperature, the $\mathrm{Y} / \mathrm{T}$ for the specimens tested at 0.0127 $\mathrm{cm} / \mathrm{minute}$ was about 0.60 and the $\mathrm{Y} / \mathrm{T}$ for the specimens tested at the crosshead speed of $0.127 \mathrm{~cm} / \mathrm{minute}$ was about 0.80 .

Figures 24 and 25 show the UTS and YS results for specimens taken from the ASTM $\mathrm{T}$-L direction and tested at crosshead speeds of 0.0127 and $0.127 \mathrm{~cm} / \mathrm{minute}$. Both the UTS and YS decrease continuously as the test temperature increased from $593{ }^{\circ} \mathrm{C}$ to $677^{\circ} \mathrm{C}$. Figure 24 shows that at a crosshead speed of $0.0127 \mathrm{~cm} / \mathrm{minute}$, the UTS decreased from $245 \mathrm{MPa}$ to $125 \mathrm{MPa}$ at $677{ }^{\circ} \mathrm{C}$, and that the YS, at these same temperatures decreased from $150 \mathrm{MPa}$ to $75 \mathrm{MPa}$. At the higher crosshead speed, $0.127 \mathrm{~cm} / \mathrm{minute}$ and figure 25, the UTS decreased from $245 \mathrm{MPa}$ to $140 \mathrm{MPa}$, and the YS decreased from $185 \mathrm{MPa}$ to $110 \mathrm{MPa}$.

For both test orientations ( $\mathrm{T}-\mathrm{L}$ or $\mathrm{L}-\mathrm{T}$ ), the $\mathrm{Y} / \mathrm{T}$ ratio was unaffected by test temperature or time at temperature. Regardless of these variables - time at temperature or test temperature - the $\mathrm{Y} / \mathrm{T}$ ratio for specimens tested at 0.0127 $\mathrm{cm} / \mathrm{minute}$ was about 0.60 and about 0.80 for specimens tested at the crosshead speed of $0.127 \mathrm{~cm} / \mathrm{minute}$. 
The measured ductility was consistent with conclusions reported by Smith (10) in A paper on the elevated temperature properties of carbon steels. The ductility, as measured by the elongation and reduction-in-area, increased as the test temperature was raised above the maximum strain ageing temperature of $316{ }^{\circ} \mathrm{C}$ $\left(600^{\circ} \mathrm{F}\right)$. The test results indicate that with increasing temperature both the UTS and YS decrease continuously, indicating that dynamic strain ageing probably did not affect these strength properties over the test temperatures used in this investigation. These results are in agreement with Peterson (11) and Miller (12) who both found that dynamic strain ageing effects were not observed on a large number of carbon steels in hot-tensile tests conducted above $316{ }^{\circ} \mathrm{C}$.

\section{Stress-Rupture Properties:}

The results of the stress-rupture tests were in good agreement with the results of the hot-tensile tests. Tables 7 and 8 show the results of the stress-rupture tests, which are plotted in Figure 26. The UTS values at the controlled crosshead speeds were equivalent to rupture lifetimes of approximately 10 minutes or less at the test temperatures of $593,621,649$, and $677^{\circ} \mathrm{C}$. White et.al (13), and corroborated by Early (14), found that for a carbon steel the tensile strength values in the temperature range of $649{ }^{\circ} \mathrm{C}$ to $704{ }^{\circ} \mathrm{C}$ correspond to rupture lifetimes of 0.15 hours or less. Thus the equivalent rupture lifetimes of the elevated-temperature tensile strength values for this work are consistent with the equivalent rupture lifetimes reported for a carbon steel.

This research has confirmed that the rupture lifetime is strongly dependent on the initial applied stress level. Figure 26 is a plot of the logarithm of the applied, or initial stress level as a function of the logarithm of the time-to rupture. By extrapolation of the stress-rupture data, i.e., using the equations representing each temperature, it can be shown that rupture time could be increased by decreasing the 10-minute lifetime stress level. Table 9 shows a compilation of these results. At $593{ }^{\circ} \mathrm{C}$, by decreasing the 10 -minute lifetime stress $27 \%$, the rupture life increased to 3 hours; an eighteen fold increase. Similarly at $677^{\circ} \mathrm{C}$, by decreasing the 10 -minute-lifetime stress $43 \%$, the rupture life increased to 3 hours. It should be noted that the 10 -minute lifetime stresses at $593{ }^{\circ} \mathrm{C}$ and $677{ }^{\circ} \mathrm{C}$ were $234 \mathrm{MPa}$ (34 ksi) and $124 \mathrm{MPa}$ (18 ksi), respectively, and these values were significantly lower than room temperature UTS or YS values for the steel.

Included in Tables 7 and 8 is a value K. Davies, et.al (15), and later Monkman and Grant (16) found that the product of the rupture life and the minimum creep rate is a constant. This constant was also found to be independent of the applied stress and temperature. Figure 27 shows a plot of the log of the minimum creep rate, determined from the stress rupture tests, versus the log of the rupture time as function of test temperature for normalized and stress relieved AAR TCl28 grade B steel. The figure verifies Davies', and Monkman's and Grant's research that the product of the rupture life and the minimum creep rate was a constant. The relationship between the minimum creep rate and applied stress was also evaluated, and figure 28 shows the relationships as a function of test temperature. Power law fits were used and the resultant curves are shown. Using figures 27 and 28 an estimate of the rupture life of the steel at a given temperature could be obtained knowing the applied stress. 
The results indicate that, in an accident where a fire is involved, the stressrupture time of this steel could be enhanced by reducing the time during which the tank car experiences the maximum internal pressure or by reducing the maximum internal pressure. The elevated-temperature rupture lifetime properties could possibly be achieved by using additional relief valves, larger flow capacity relief valves, or lower opening pressure relief valves.

\section{Fracture Toughness Properties:}

Fracture toughness tests were conducted on both the normalized, and normalized and stress relieved steel at 593, 621, 649, and $677^{\circ} \mathrm{C}$. Compact tension specimens were taken from both the ASTM T-L and L-T directions, and the results are shown in Table 10 and plotted in figure 27. In determining the fracture toughness, a small crack was grown in the specimen by fatiguing. A load was applied with the intention of propagating the initial crack. For all specimens and at each test temperature, crack growth did not occur after application of the load, indicating that the steel had sufficient energy to prevent the initial fatigue crack from propagating. The maximum load was used to calculate the J value which was then used to calculate the fracture toughness value $\mathrm{K}$. (See Table 10).

Figure 27 shows that as the test temperature increased, the fracture toughness decreased. This is due to the fact that the primary mechanical property responsible for the resultant fracture toughness for the steel is the yield strength. As shown earlier in figures 24 and 25 , the yield strength decreased continuously as the test temperature increased, hence the fracture toughness would be expected to follow the same trend. Test specimen orientation response (governed by inclusion orientation and rolling direction of the plate), also shown earlier in the same figures, was also followed. That is, the fracture toughness values for the L-T specimens, for both the normalized, and normalized and stress relieved conditions, were greater than the fracture toughness for the specimens taken from the $\mathrm{T}-\mathrm{L}$ direction. Due to inadequate plate material, only one test specimen taken from the L-T direction was tested at $593{ }^{\circ} \mathrm{C}$. Its fracture toughness followed the same general trend as that observed for the normalized and stress relieved material. These test results indicate that the steel even at $677{ }^{\circ} \mathrm{C}$ is highly resistant to both crack initiation and propagation. 
1. The chemical analysis of the as-received plate showed that the steel was within the limits stated in the specification.

2. Metallographic examination of the as-received steel in the unetched condition revealed that the steel was relatively clean, that is, it did not contain a significant number of inclusions. Inclusions normally found in this steel affect the mechanical properties.

3. Specimens were heat treated to determine the affects of temperature and time on the microstructure. Examination of the specimens in the etched condition showed that there was not a significant effect on the microstructure. The proeutectoid ferrite/pearlite did not grow to where it would affect the properties evaluated in this paper. Although the maximum temperature used in this study $\left(677{ }^{\circ} \mathrm{C}\right)$ was higher than the stress relieving temperature $\left(649^{\circ} \mathrm{C}\right)$, no dramatic change in the microstructure was observed.

4. Hardness measurements taken on these same specimens showed that only at $677{ }^{\circ} \mathrm{C}$ was there a noticeable decrease in the hardness. This decrease appears to be due to the slight increase in the proeutectoid ferrite in the steel.

5. The hot-tensile properties were found to be anisotropic, that is they were affected by the inclusions present in the steel. Both the UTS and YS were essentially uniform with time. Representative curves of these data showed them to be essentially linear with temperature. The elevated temperature tensile properties were significantly lower than the ambient temperature mechanical properties. Increasing the crosshead speed affected the YS more than the UTS, since the YS is more rate sensitive than the UTS.

6. The stress-rupture properties were highly dependent on the applied stress level. The product of rupture life and minimum creep rate was found to be constant. Relationships were developed that could predict the rupture life at a particular temperature and an applied stress level. The stress-rupture time of this steel could be enhanced by reducing the time during which a tank car experiences the maximum internal pressure or by reducing the maximum internal pressure. The elevated-temperature rupture lifetime properties could possibly be extended by using additional relief valves, larger flow capacity relief valves, or lower opening pressure relief valves.

7. Fracture toughness tests as a function of temperature showed that at temperatures up to $650{ }^{\circ} \mathrm{C}$, the fracture toughness was greater for the normalized and stress relieved steel than for the normalized steel. Catastrophic failure did not occur, that is the elastic strain energy present in the steel was able to prevent a pre-existing crack from propagating in a rapid manner. The fracture toughness for the specimens tested in the ASTM L-T direction was greater than that for specimens tested in the ASTM T-L direction in the plate. 


\section{REFERENCES}

1. G. E. Hicho, "Crack Árrest Fracture Toughness Measurements of Normalized and Inclusion Shape Controlled AAR TC128 Grade B Steel, and Micro-Alloyed, Control-Rolled, and Inclusion Shape Controlled A 8XX Grade B Steel," NISTIR 4501, February 1991.

2. G. E. Hicho and D. E. Harne, "Mechanical Properties and Fracture Toughness of AAR TC128 Grade B Steel in the Normalized and Normalized and Stress Relieved Conditions," NISTIR 4660, September 1991.

3. C. Anderson, W. Townsend, J. Zook, and G. Cowgill, "The Affects of a Fire Environment on a Rail Tank Car Filled with LPG," FRA-OR\&D 75-31, USA Ballistic Research Laboratories, Aberdeen Proving Ground, Maryland, 1974.

4. W. Townsend, C. Anderson, J. Zook, and G. Cowgill, "Comparison of Thermally Coated and Uninsulated Rail Tank Cars Filled with LPG Subjected to a Fire Environment," FRA-OR\&D 75-32, USA Ballistic Research Laboratories, Aberdeen Proving Ground, Maryland, 1974.

5. J. G. Early and C. G. Interrante, "A Metallurgical Investigation of a FullScale Insulated Rail Tank Car Filled with LPG Subjected to a Fire Environment," FRA-OR\&D 75-52, January 1975.

6. C. G. Interrante, J. G. Early, and G. E. Hicho, "Analysis of Findings of Four Tank Car Accident Reports," FRA-OR\&D 75-50, January 1975.

7. "Phase 1 Report on Summary of Ruptured Tank Cars Involved in Past Accidents," Report RA-01-2-7, Railroad Tank Car Safety Research and Test Project, Association of American Railroads, Chicago, IL, July 1, 1972.

8. G. E. Hicho and J. H. Smith, "Mechanical Properties and Fracture Toughness of AAR TC128 Grade B Steel and Micro-alloyed, Control-Rolled Steel, A 8XX Grade B, from - 80 F to +73 F," NISTIR 4289, April 1990.

9. G. E. Hicho and J. H. Smith, "Determination of the NDT Temperature and Impact Properties of AAR TC128 Grade B Steel and A 8XX Grade B Stee1," NISTIR 4300, April 1990.

10. G. V. Smith, "Elevated Temperature Static Properties of Wrought Carbon Steels," ASTM STP 503, 1972.

11. J. L. Peterson, "Strain Hardening in Hypoeutectoid Steels, " Trans. ASM, 56, $304,1963$.

12. R. F. Miller, "The Strength of Carbon Steels for Elevated-Temperature Applications," ASTM Proc. 54, 964, 1954.

13. A. E. White, C. L. Clark, and R. L. Wilson, "The Fracture of Carbon Steels at Elevated Temperatures," Trans. ASM 25, 863, 1937. 
14. J. G. Early, "Report No. 8. Ambient-and Elevated-Temperature Mechanical Properties of AAR M128-69-B Steel Plate Samples Taken from Fire Tested Insulated Tank Car RAX 202," May 1975.

15. P. W. Davies, B. Wilshire, "An Interpretation of the Relationship between Creep and Fracture," Structural Processes in Creep. The Iron and Steel Institute, pp. 34-55, 1961.

16. F. Monkman and N. J. Grant, "An Empirical Relationship between Rupture Life and Minimum Creep Rate in Creep-Rupture tests," Trans. ASM, Vol. 1 pp. 593-620, 1956. 
Table 1. Chemical Composition (wt\%), AAR Specification, Heat and Check Analysis for Plate "J".

\begin{tabular}{|c|c|c|c|}
\hline Element $(\%)$ & $\begin{array}{c}\mathrm{AAR}^{\uparrow} \\
\text { Specification }\end{array}$ & $\begin{array}{c}\text { Heat }^{2} \\
\text { Analysis }\end{array}$ & $\begin{array}{l}\text { Check }^{3} \\
\text { Analysis }\end{array}$ \\
\hline Carbon & $0.25 \max$ & 0.22 & .21 \\
\hline Manganese & $1.0-1.5$ & 1.27 & 1.34 \\
\hline Phosphorous & $0.035 \max$ & 0.015 & 0.017 \\
\hline Sulfur & $0.040 \max$ & 0.012 & 0.012 \\
\hline Silicon & $0.05-0.50$ & 0.241 & 0.26 \\
\hline Nickel & $0.25 \max$ & 0.04 & 0.03 \\
\hline Chromium & $0.25 \max$ & 0.23 & 0.26 \\
\hline Molybdenum & $0.08 \max$ & 0.062 & 0.07 \\
\hline Copper & $0.035 \max$ & 0.034 & 0.04 \\
\hline Vanadium & $0.08 \max$ & 0.034 & 0.036 \\
\hline Aluminum & $\mathrm{NS}^{4}$ & 0.065 & 0.070 \\
\hline Nitrogen & NS & NS & 0.0067 \\
\hline$C E^{5}$ & 0.62 & 0.50 & 0.51 \\
\hline
\end{tabular}

1 AAR Specification for Tank Cars; M-1002, M-128

2 Bethlehem Steel Corporation

3 National Institute of Standards \& Technology

4 Not Specified

${ }^{5} \mathrm{CE}(\%)=\mathrm{C}+\mathrm{Mn} / 6+(\mathrm{Cr}+\mathrm{Mo}+\mathrm{V}) / 5+(\mathrm{Cu}+\mathrm{Ni}) / 15$ 
Table 2. Hardness, Rockwell A; for Coupons that were Heat Treated at 593, 621, 649, and $677^{\circ} \mathrm{C}$ for 30, 60, 90, and 120 Minutes.

\begin{tabular}{lcccccccc}
$\begin{array}{l}\text { Time at } \\
\text { Temp. (min) }\end{array}$ & $\begin{array}{c}\text { Temp. } \\
{ }^{\circ} \mathrm{C}\end{array}$ & $\begin{array}{c}\text { Hard } \\
\text { (HRA) } 1\end{array}$ & $\begin{array}{c}\text { Temp. } \\
{ }^{\circ} \mathrm{C}\end{array}$ & $\begin{array}{c}\text { Hard } \\
\text { (HRA) }\end{array}$ & $\begin{array}{c}\text { Temp. } \\
{ }^{\circ} \mathrm{C}\end{array}$ & $\begin{array}{c}\text { Hard } \\
\text { (HRA) }\end{array}$ & $\begin{array}{c}\text { Temp. } \\
{ }^{\circ} \mathrm{C}\end{array}$ & $\begin{array}{c}\text { Hard } \\
\text { (HRA) }\end{array}$ \\
\hline 30 & 593 & 81.8 & 621 & 81.5 & 649 & 81.6 & 677 & 81.2 \\
60 & 593 & 81.5 & 621 & 81.7 & 649 & 81.7 & 677 & 80.2 \\
90 & 593 & 81.5 & 621 & 81.6 & 649 & 81.6 & 677 & 80.5 \\
120 & 593 & 81.9 & 621 & 81.7 & 649 & 82.1 & 677 & 80.6
\end{tabular}

1 Average of four readings 
Table 3. Tensile test results for specimens tested at 593, 621, 649, and $677{ }^{\circ} \mathrm{C}$ for 60,90 , and 120 minutes. Crosshead speed was $0.0127 \mathrm{~cm} / \mathrm{min}$. The specimens were taken from the ASTM T-L direction, i.e., long axis of the specimen was parallel to the rolling direction of the plate.

\begin{tabular}{|c|c|c|c|c|c|c|}
\hline $\begin{array}{l}\text { Specimen } \\
\text { No. }\end{array}$ & $\begin{array}{l}\text { Test } \\
\text { Temp. } \\
\left({ }^{\circ} \mathrm{C}\right)\end{array}$ & $\begin{array}{c}\text { Time at } \\
\text { Temperature } \\
\text { (Min) }\end{array}$ & $\begin{array}{c}\text { UTS } \\
(\mathrm{MPa})\end{array}$ & $\begin{array}{c}\mathrm{YS} \\
(0.2 \%) \\
(\mathrm{MPa}) \\
\end{array}$ & $\begin{array}{l}\text { Elong. } \\
25.4 \mathrm{~mm} . \\
(\%)\end{array}$ & $\begin{array}{l}\text { RA } \\
(\%)\end{array}$ \\
\hline 2 & 677 & 120 & 119.2 & 77.9 & $\mathrm{ND}^{1}$ & 93.7 \\
\hline 4 & 677 & 120 & 121.3 & 77.9 & $\mathrm{ND}^{1}$ & 92.6 \\
\hline 6 & 677 & 90 & 123.3 & 77.7 & $\mathrm{ND}^{1}$ & 92.8 \\
\hline 8 & 677 & 60 & 123.3 & 82.7 & $\mathrm{ND}^{1}$ & 93.0 \\
\hline 11 & 649 & 60 & 153.0 & 95.8 & 78.0 & 88.2 \\
\hline 13 & 649 & 90 & 155.7 & 105.4 & 78.1 & 86.4 \\
\hline 15 & 649 & 120 & 156.4 & 102.0 & 76.1 & 77.2 \\
\hline 17 & 621 & 60 & 194.3 & 122.0 & 56.9 & 78.8 \\
\hline 19 & 621 & 90 & 195.7 & 126.8 & 57.4 & 79.7 \\
\hline 21 & 621 & 120 & 192.2 & 119.9 & 62.8 & 82.4 \\
\hline 23 & 593 & 60 & 236.6 & 150.2 & 58.0 & 74.2 \\
\hline 25 & 593 & 90 & 234.9 & 148.8 & 57.4 & 74.3 \\
\hline 27 & 593 & 120 & 237.7 & 153.6 & 40.0 & 75.7 \\
\hline
\end{tabular}

1 Not determined, gage marks obliterated during test. 
Table 4. Tensile test results for specimens tested at 593, 621, 649, and $677^{\circ} \mathrm{C}$ for 60,90 , and 120 minutes. Crosshead speed was $0.127 \mathrm{~cm} / \mathrm{min}$. The specimens were taken from the ASTM T-L direction, i.e., long axis of the specimen was transverse to the rolling direction of the plate.

\begin{tabular}{|c|c|c|c|c|c|c|}
\hline $\begin{array}{l}\text { Specimen } \\
\text { No. }\end{array}$ & $\begin{array}{l}\text { Test } \\
\text { Temp. } \\
\left({ }^{\circ} \mathrm{C}\right)\end{array}$ & $\begin{array}{c}\text { Time at } \\
\text { Temperature } \\
\text { (Min) }\end{array}$ & $\begin{array}{c}\text { UTS } \\
(\mathrm{MPa})\end{array}$ & $\begin{array}{c}\mathrm{YS} \\
(0.2 \%) \\
(\mathrm{MPa}) \\
\end{array}$ & $\begin{array}{l}\text { Elong. } \\
25.4 \mathrm{~mm} . \\
(\%)\end{array}$ & $\begin{array}{l}\text { RA } \\
(\%)\end{array}$ \\
\hline 5 & 677 & 120 & 119.9 & 106.8 & $\mathrm{ND}^{1}$ & 93.4 \\
\hline 7 & 677 & 90 & 123.3 & 102.7 & $\mathrm{ND}^{1}$ & 92.9 \\
\hline 10 & 677 & 60 & 126.1 & 104.9 & $\mathrm{ND}^{1}$ & 92.0 \\
\hline 12 & 649 & 60 & 160.5 & 135.7 & 64.6 & 84.7 \\
\hline 14 & 649 & 90 & 157.8 & 128.8 & 80.0 & 87.3 \\
\hline 16 & 649 & 120 & 159.8 & 132.3 & 68.7 & 87.2 \\
\hline 18 & 621 & 60 & 197.1 & 155.7 & 66.2 & 85.9 \\
\hline 20 & 621 & 90 & 194.3 & 153.4 & 68.0 & 79.5 \\
\hline 22 & 621 & 120 & 189.5 & 141.9 & 61.1 & 79.0 \\
\hline 24 & 593 & 60 & 241.2 & 172.9 & 60.6 & 72.3 \\
\hline 29 & 593 & 90 & 243.9 & 172.9 & 58.8 & 73.5 \\
\hline 28 & 593 & 120 & 241.8 & 185.3 & 55.0 & 74.9 \\
\hline
\end{tabular}

1 Not determined, gage marks obliterated during test. 
Table 5. Tensile test results for specimens tested at 593, 621, 649, and $677^{\circ} \mathrm{C}$ for 60,90 , and 120 minutes. Crosshead speed was $0.0127 \mathrm{~cm} / \mathrm{min}$. The specimens were taken from the ASTM L-T direction, i.e., long axis of the specimen was transverse to the rolling direction of the plate.

\begin{tabular}{ccccccc}
$\begin{array}{c}\text { Specimen } \\
\text { No. }\end{array}$ & $\begin{array}{l}\text { Test } \\
\text { Temp. } \\
\left({ }^{\circ} \mathrm{C}\right)\end{array}$ & $\begin{array}{c}\text { Time at } \\
\text { Temperature } \\
(\text { Min) }\end{array}$ & $\begin{array}{c}\text { UTS } \\
(\mathrm{MPa})\end{array}$ & $\begin{array}{c}\text { YS } \\
(\mathbf{M P a})\end{array}$ & $\begin{array}{c}\text { E1ong. } \\
25.4 \mathrm{~mm} . \\
(\%)\end{array}$ & $\begin{array}{c}\text { RA } \\
(\%)\end{array}$ \\
\hline & & & & & & \\
66 & 677 & 120 & 119.9 & 77.2 & 70.5 & 93.5 \\
68 & 677 & 90 & 123.3 & 75.8 & 82.0 & 93.5 \\
70 & 677 & 60 & 123.3 & 75.8 & 88.1 & 93.4 \\
72 & 649 & 60 & 161.2 & 105.4 & 66.1 & 87.4 \\
90 & 649 & 90 & 159.3 & 102.7 & 66.6 & 84.2 \\
76 & 649 & 120 & 148.8 & 98.5 & 61.5 & 87.3 \\
78 & 621 & 60 & 195.0 & 131.6 & 66.5 & 79.8 \\
80 & 621 & 90 & 191.8 & 121.3 & 55.0 & 80.9 \\
82 & 621 & 120 & 194.3 & 124.7 & 65.6 & 79.9 \\
92 & & & & & & 75.8 \\
86 & 593 & 60 & 253.6 & 157.0 & 42.1 & 71.2 \\
88 & 593 & 90 & 243.2 & 155.0 & 50.5 & 71.5
\end{tabular}


Table 6. Tensile test results for specimens tested at 593, 621, 649, and $677^{\circ} \mathrm{C}$ for 60,90 , and 120 minutes. Crosshead speed was $0.127 \mathrm{~cm} / \mathrm{min}$. The specimens were taken from the ASTM L-T direction, i.e., long axis of the specimen was transverse to the rolling direction of the plate.

\begin{tabular}{ccccccc}
$\begin{array}{c}\text { Specimen } \\
\text { No. }\end{array}$ & $\begin{array}{l}\text { Test } \\
\text { Temp. } \\
\left({ }^{\circ} \mathrm{C}\right)\end{array}$ & $\begin{array}{c}\text { Time at } \\
\text { Temperature } \\
(\text { Min) }\end{array}$ & $\begin{array}{c}\text { UTS } \\
(\mathrm{MPa})\end{array}$ & $\begin{array}{c}\text { YS } \\
(0.2 \%) \\
(\mathrm{MPa})\end{array}$ & $\begin{array}{c}\text { E1ong. } \\
25.4 \mathrm{~mm} . \\
(\%)\end{array}$ & $\begin{array}{c}\text { RA } \\
(\%)\end{array}$ \\
\hline & & & & & & \\
67 & 677 & 120 & 122.0 & 104.0 & 80.8 & 92.7 \\
69 & 677 & 90 & 126.1 & 98.5 & 88.8 & 92.1 \\
71 & 677 & 60 & 126.1 & 101.3 & 88.4 & 91.0 \\
73 & 649 & 60 & 157.1 & 121.9 & 72.8 & 86.2 \\
75 & 649 & 90 & 154.1 & 121.9 & 60.1 & 85.2 \\
77 & 649 & 120 & 155.7 & 126.8 & 65.4 & 86.3 \\
79 & 621 & 60 & 195.7 & 147.4 & 60.5 & 78.4 \\
81 & 621 & 90 & 196.4 & 148.1 & 54.8 & 77.6 \\
83 & 621 & 120 & 195.6 & 150.2 & 61.1 & 78.4 \\
91 & & & & & & \\
87 & 593 & 60 & 241.2 & 178.5 & 58.3 & 71.0 \\
89 & 593 & 90 & 245.3 & 178.5 & 45.5 & 69.7 \\
& 593 & 120 & 249.4 & 192.6 & 44.3 & 72.7
\end{tabular}


Table 7. Stress-rupture test results for specimens that were tested at $593{ }^{\circ} \mathrm{C}$ and $621{ }^{\circ} \mathrm{C}$ at the indicated applied stresses.

\begin{tabular}{rlrrrrr}
$\begin{array}{c}\text { Specimen } \\
\text { No. }\end{array}$ & $\begin{array}{l}\text { Test } \\
\text { Temp. } \\
\left({ }^{\circ} \mathrm{C}\right)\end{array}$ & $\begin{array}{c}\text { Applied } \\
\text { Stress } \\
(\text { MPa })\end{array}$ & $\begin{array}{c}\text { Time to } \\
\text { Failure } \\
\text { (Min) }\end{array}$ & $\begin{array}{r}\text { Elong. } \\
25.4 \mathrm{~mm} . \\
(\%)\end{array}$ & $\begin{array}{r}\text { RA } \\
(\%)\end{array}$ & $\mathrm{K}^{1}$ \\
\hline & & & & & & \\
32 & 593 & 170.2 & 170 & 56.2 & 70.6 & 23.0 \\
34 & 593 & 189.5 & 71 & 55.0 & 72.1 & 22.4 \\
40 & 593 & 213.6 & 27 & 58.4 & 74.8 & 22.8 \\
45 & 593 & 179.1 & 131 & 56.7 & 70.9 & 21.6 \\
46 & 593 & 199.8 & 49 & 60.6 & 70.8 & 22.3 \\
49 & 593 & 184.0 & 127 & 56.9 & 68.6 & 20.9 \\
54 & 593 & 186.0 & 84 & 53.0 & 69.8 & 23.3 \\
& & & & & & \\
30 & 621 & 126.1 & 240 & 74.0 & 78.9 & 23.9 \\
33 & 621 & 126.8 & 219 & 66.6 & 81.5 & 21.9 \\
37 & 621 & 158.5 & 53 & 67.7 & 83.0 & 25.0 \\
38 & 621 & 144.7 & 85 & 69.4 & 76.4 & 23.0 \\
39 & 621 & 186.0 & 12 & 56.2 & 76.0 & 18.0 \\
47 & 621 & 144.7 & 113 & 87.2 & 81.7 & 24.9 \\
48 & 621 & 137.8 & 129 & 66.7 & 78.6 & 24.0 \\
53 & 621 & 128.2 & 236 & ND & 79.4 & 22.2
\end{tabular}

$K=t_{f} *(\epsilon)$ where $t_{f}=$ time to failure and $\epsilon=$ minimum creep rate, mcr. 2 Not determined. 
Table 8. Stress-rupture test results for specimens that were tested at $649{ }^{\circ} \mathrm{C}$ and $677^{\circ} \mathrm{C}$ at the indicated applied stresses.

\begin{tabular}{ccccccc}
$\begin{array}{c}\text { Specimen } \\
\text { No. }\end{array}$ & $\begin{array}{l}\text { Test } \\
\text { Temp. } \\
\left({ }^{\circ} \mathrm{C}\right)\end{array}$ & $\begin{array}{c}\text { Applied } \\
\text { Stress } \\
\text { (MPa) }\end{array}$ & $\begin{array}{c}\text { Time to } \\
\text { Failure } \\
\text { (Min) }\end{array}$ & $\begin{array}{c}\text { Elong. } \\
25.4 \mathrm{~mm} \\
(\%)\end{array}$ & $\begin{array}{r}\text { RA } \\
(\%)\end{array}$ & $\mathrm{K}^{1}$ \\
\hline & & & & & & \\
36 & 649 & 105.4 & 115 & 79.5 & 87.4 & 26.9 \\
41 & 649 & 144.7 & 19 & 65.0 & 83.0 & 22.0 \\
42 & 649 & 117.1 & 75 & 65.1 & 82.9 & ND $^{2}$ \\
50 & 649 & 130.9 & 33 & 87.2 & 86.6 & 23.7 \\
51 & 649 & 113.7 & 90 & 81.1 & 86.9 & 24.3 \\
35 & 677 & & & & & \\
43 & 677 & 94.1 & 78 & 96.7 & 92.0 & 26.0 \\
44 & 677 & 110.2 & 22 & 71.9 & 92.3 & 24.3 \\
52 & 677 & 89.6 & 75 & 93.6 & 92.6 & 24.2 \\
& & & & 96.6 & 93.8 & 24.9
\end{tabular}

$1 \mathrm{~K}=t_{f} *(\epsilon)$ where $t_{f}=$ time to failure and $\epsilon^{*}=$ minimum creep rate, mcr.

2 Not determined.

Table 9. Effects of decreasing the 10-minute lifetime stress on the rupture life.

Increase in Rupture Life

\begin{tabular}{cccccccc} 
Temperature & $\begin{array}{c}\text { 10-Minute } \\
\text { Lifetime } \\
\text { Stress (MPa) }\end{array}$ & $\begin{array}{l}\text { One } \\
\text { Hour }\end{array}$ & Stress & $\begin{array}{c}\text { Two } \\
\text { Hours }\end{array}$ & Stress & $\begin{array}{r}\text { Three } \\
\text { Hours }\end{array}$ & Stress \\
\hline $593{ }^{\circ} \mathrm{C}$ & 234.3 & $-17 \%$ & 194.5 & $-23 \%$ & 180.4 & $-27 \%$ & 171.0 \\
$621{ }^{\circ} \mathrm{C}$ & 190.0 & $-19 \%$ & 153.9 & $-26 \%$ & 140.6 & $-30 \%$ & 133.0 \\
$649{ }^{\circ} \mathrm{C}$ & 157.2 & $-23 \%$ & 121.0 & $-33 \%$ & 105.3 & $-38 \%$ & 97.5 \\
$677{ }^{\circ} \mathrm{C}$ & 123.8 & $-27 \%$ & 90.4 & $-37 \%$ & 78.0 & $-43 \%$ & 70.6
\end{tabular}


Table 10. Fracture toughriess results for specimens tested at 593, 621, 649 , and $677^{\circ} \mathrm{C}$. Specimens were held at the respective temperature 90 minutes prior to testing.

\begin{tabular}{|c|c|c|c|c|c|c|c|}
\hline $\begin{array}{c}\text { Specimen } \\
\text { No. }\end{array}$ & $\begin{array}{c}\text { Test } \\
\text { Temp. }{ }^{\circ}{ }^{\circ} \\
\end{array}$ & Cond. ${ }^{1}$ & Orient. & $J^{2}$ & $\begin{array}{c}\text { Fracture } \\
\mathrm{J}^{3}\end{array}$ & $\begin{array}{c}\text { Toughness } \\
\mathrm{K}^{4} \\
\end{array}$ & $\mathrm{~K}^{5}$ \\
\hline CT -19 & 593 & $A+S R$ & TL & 809 & 140 & 153 & 168 \\
\hline CT -22 & 593 & $A+S R$ & $\mathrm{TL}$ & 1021 & 176 & 175 & 193 \\
\hline CT -35 & 593 & $\mathrm{~N}$ & LT & 1237 & 213 & 193 & 212 \\
\hline $\mathrm{CT}-46$ & 593 & $A+S R$ & LT & 1713 & 296 & 227 & 250 \\
\hline CT -43 & 593 & $A+S R$ & LT & 1429 & 267 & 207 & 228 \\
\hline CT -12 & 593 & $A+S R$ & TL & 632 & 109 & 138 & 152 \\
\hline CT -20 & 621 & $A+S R$ & $\mathrm{TL}$ & 647 & 112 & 139 & 153 \\
\hline CT -23 & 621 & $A+S R$ & TL & 649 & 112 & 140 & 154 \\
\hline CT - 8 & 621 & $A+S R$ & TL & 1055 & 182 & 178 & 196 \\
\hline $\mathrm{CT}-47$ & 621 & $A+S R$ & TL & 1351 & 233 & 201 & 221 \\
\hline CT -31 & 621 & $\hat{N}$ & LT & 1144 & 197 & 185 & 204 \\
\hline CT -21 & 649 & $A+S R$ & TL & 367 & 63 & 105 & 116 \\
\hline CT -24 & 649 & $A+S R$ & TL & 506 & 87 & 123 & 135 \\
\hline CT -44 & 649 & $A+S R$ & LT & 995 & 172 & 173 & 190 \\
\hline CT -48 & 649 & $A+S R$ & LT & 970 & 168 & 171 & 188 \\
\hline CT -32 & 649 & $A+S R$ & LT & 1004 & 173 & 174 & 191 \\
\hline CT -33 & 649 & $A+S R$ & LT & 964 & 166 & 170 & 187 \\
\hline CT -18 & 677 & $A+S R$ & TL & 429 & 74 & 113 & 124 \\
\hline CT -45 & 677 & $A+S R$ & LT & 686 & 118 & 143 & 157 \\
\hline $\mathrm{CT}-34$ & 677 & $\mathrm{~N}$ & LT & 745 & 129 & 150 & 165 \\
\hline CT -36 & 677 & $\mathrm{~N}$ & LT & 727 & 126 & 148 & 163 \\
\hline
\end{tabular}

A+SR: Normalized plus stress relieved $\mathrm{N}$ : $\quad$ Normalized

2 (Ft. - lbs $) / \mathrm{in}^{2}$

$3 \mathrm{KJ} / \mathrm{m}^{2}$

$4 \mathrm{Ksi} \mathrm{Hin}^{1 / 2} \quad \mathrm{~K}=(\mathrm{JE})^{1 / 2}$ where $\mathrm{E}=29 \mathrm{E} 6$

$5 \mathrm{MPa} * \mathrm{M}^{1 / 2}$ 


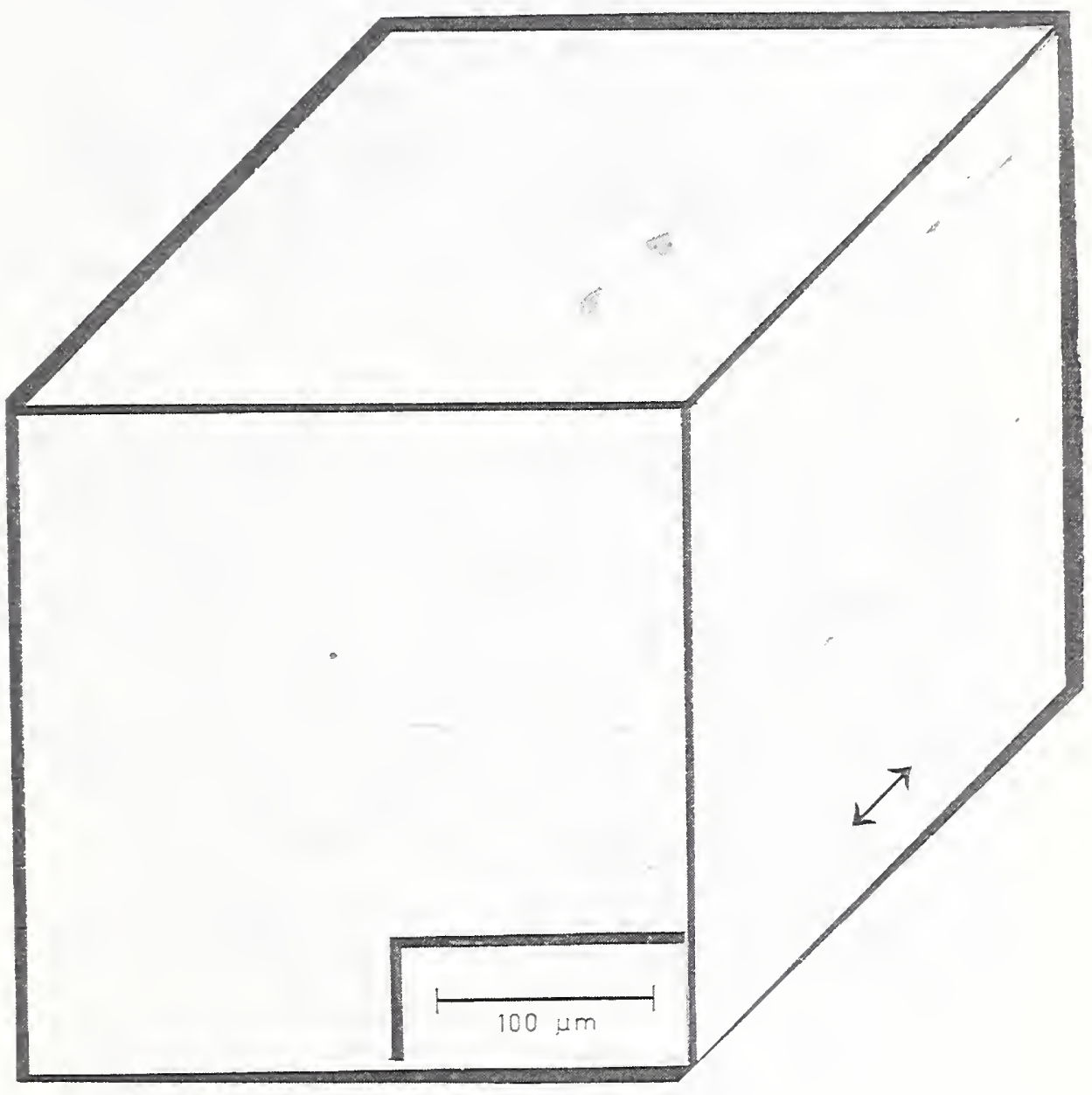

Figure 1. Photomicrographs of the as-received normalized AAR TC128 grade B steel in three orthogonal direction and in the unetched condition. Plate rolling direction shown by arrow in the photomicrograph. 


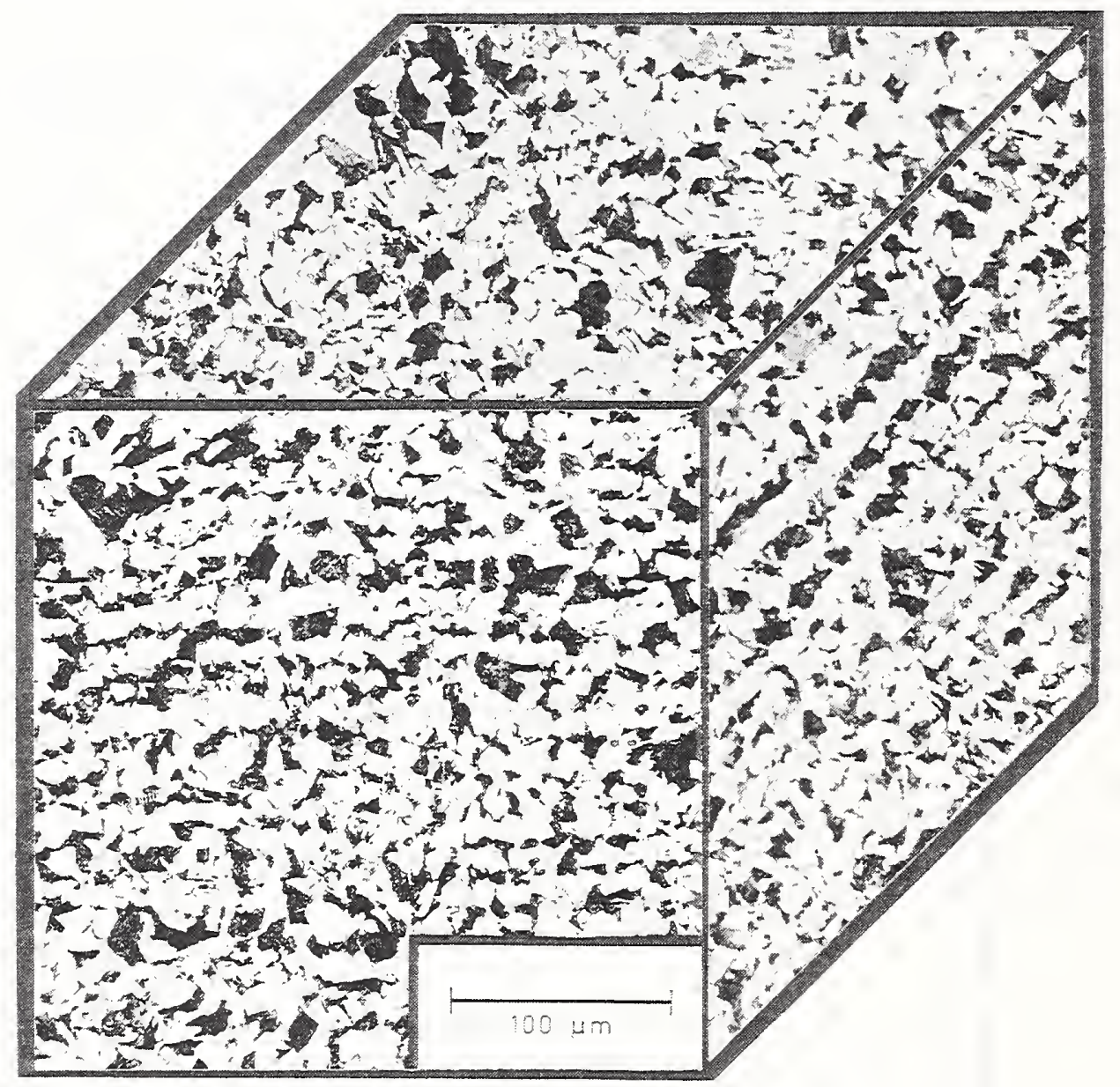

Figure 2. Photomicrographs of the as-received normalized AAR TC128 grade B steel in three orthogonal directions in the etched condition. Etch: 1\% Nital 

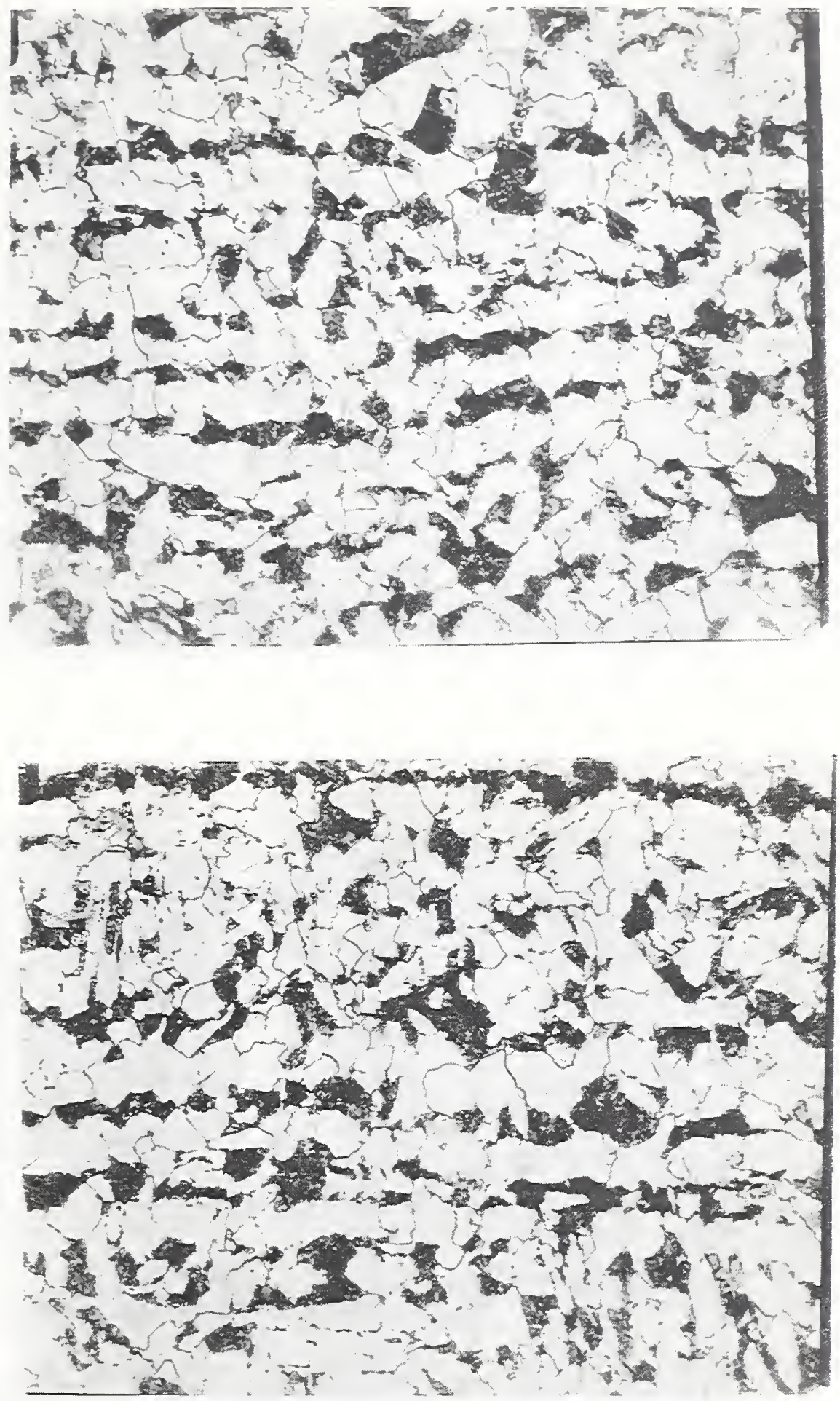

Figure 3. Photomicrographs of the as-received normalized and stress relieved AAR TC128 grade B taken at two different locations. Etch: 1\% Nital Mag. X500. 


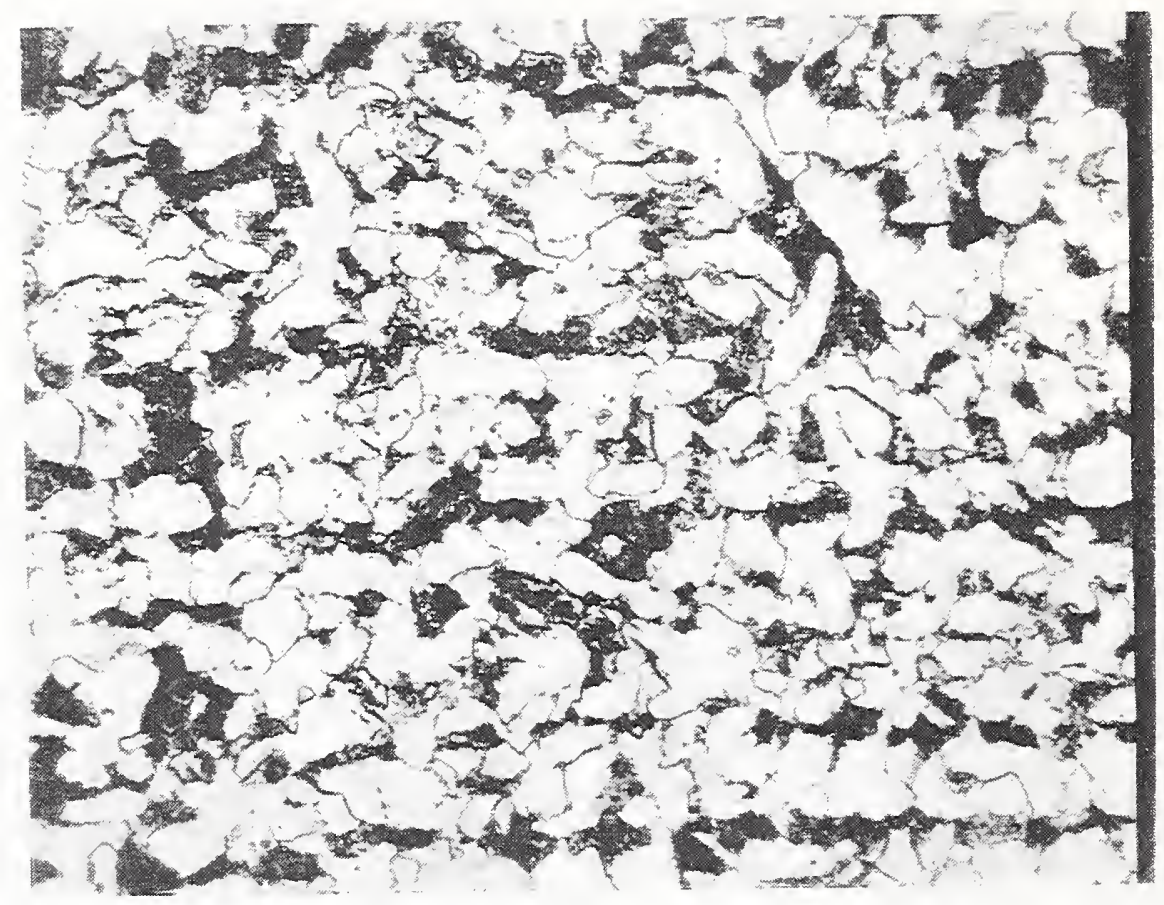

(a)

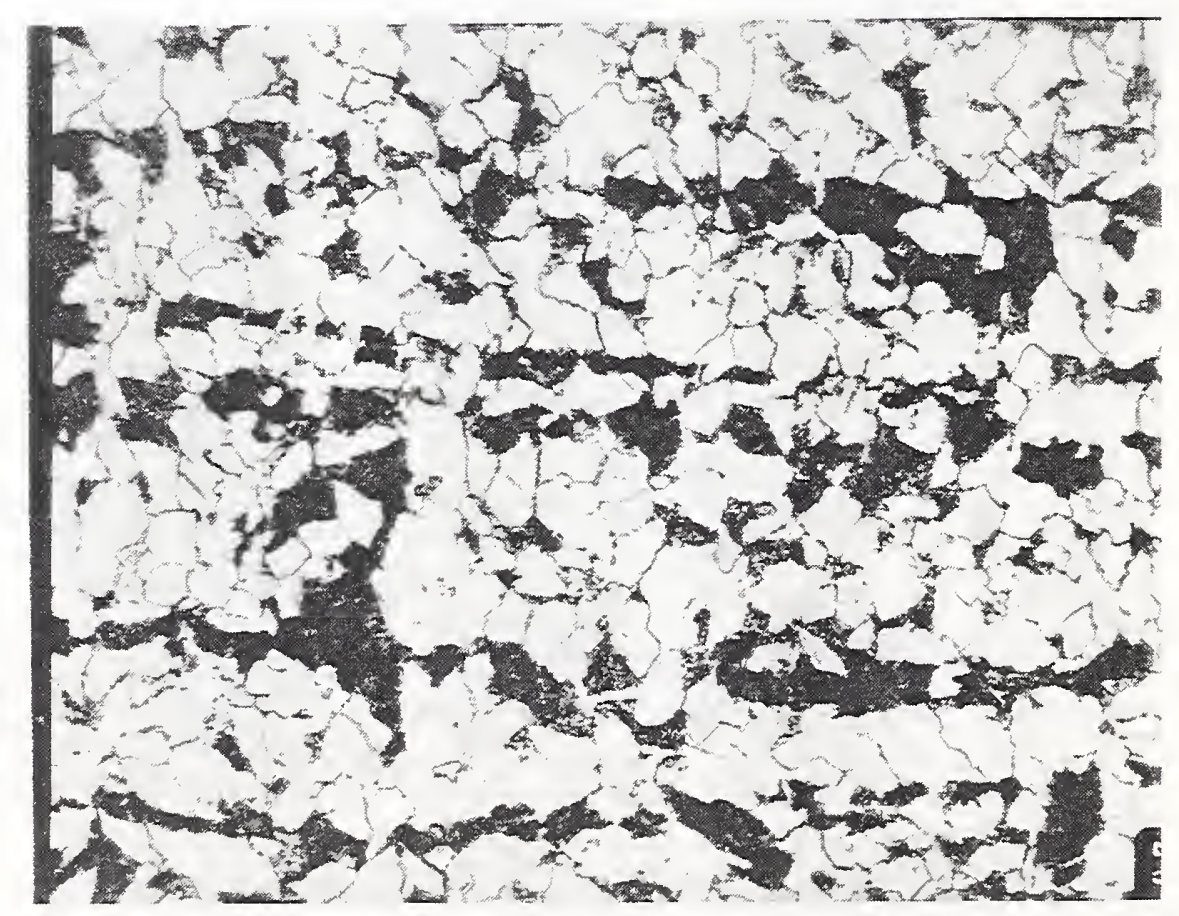

Figure 4. Photomicrographs of as-received normalized and stress relieved AAR TC128 grade B steel after 30 (a) and 60 (b) minutes at $593 \mathrm{C}$. Etch: 1\% Nital Mag. X500. 

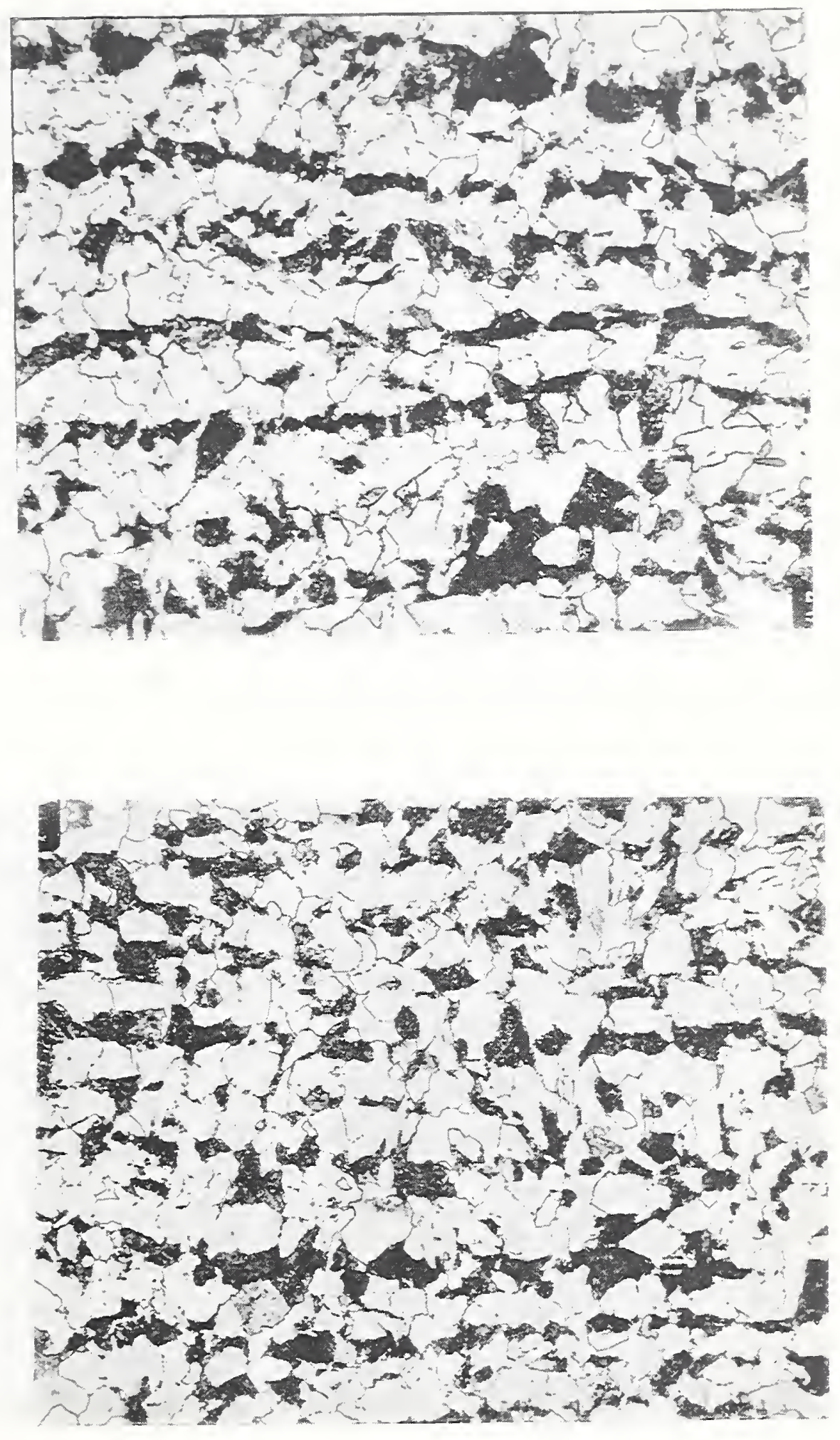

Figure 5. Photomicrographs of as-received normalized and stress relieved AAR TC128 grade B steel after 90 (a) and 120 (b) minutes at $593 \mathrm{C}$. Etch: 1\% Nital Mag. X500. 


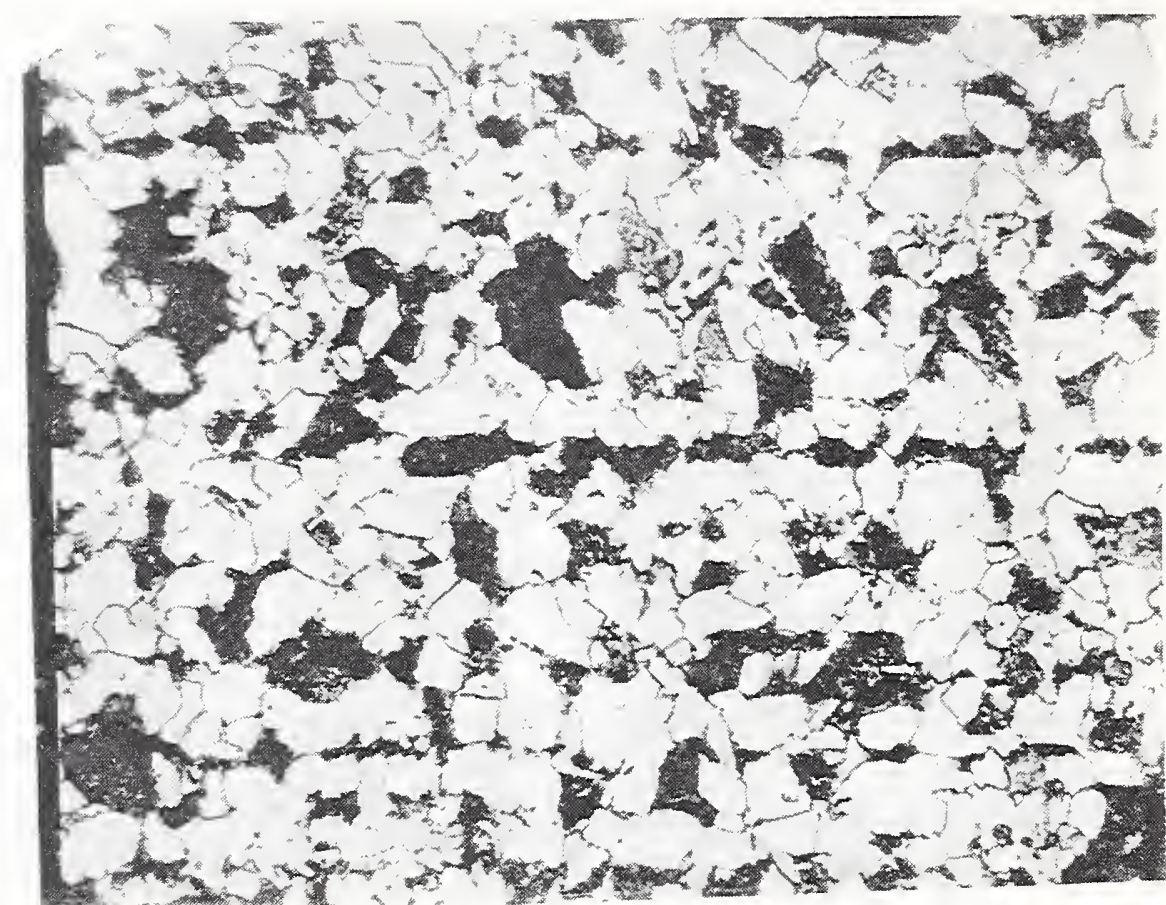

(a)

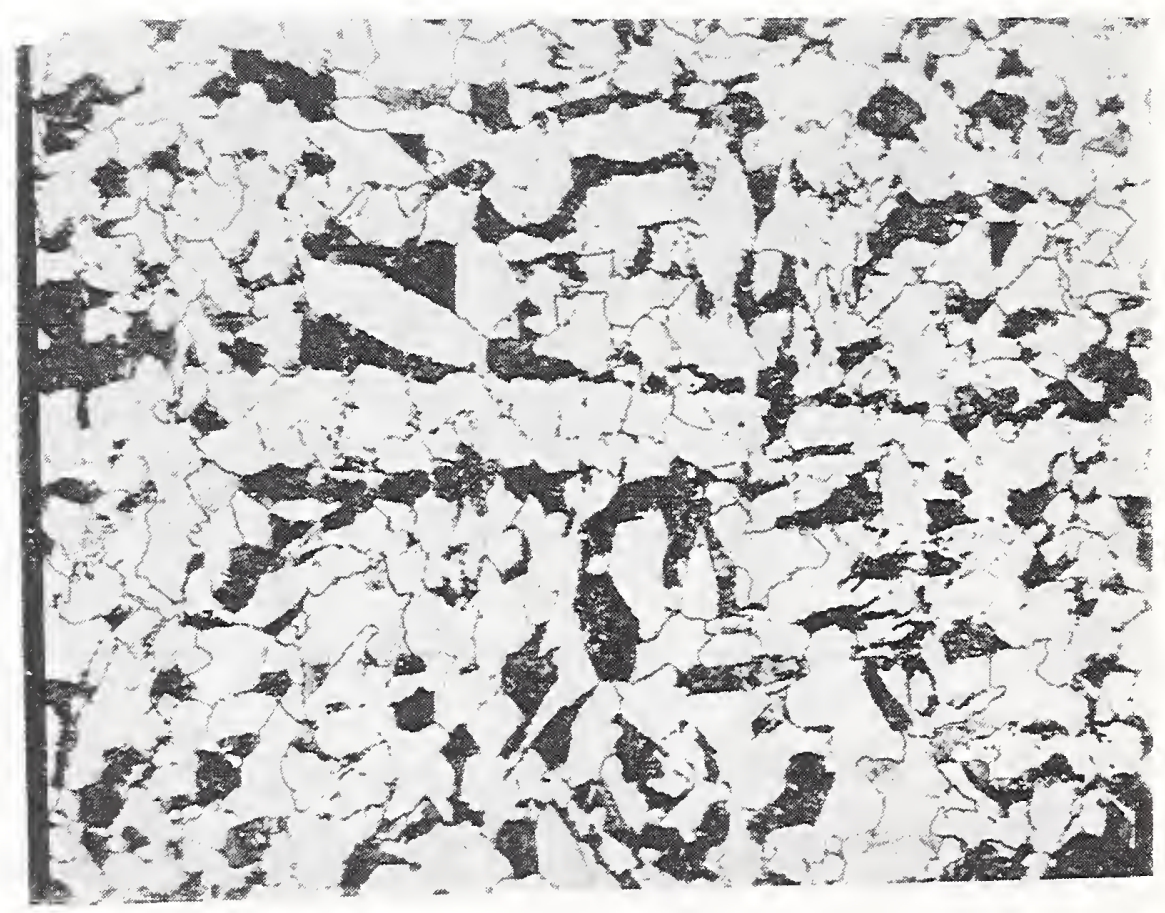

Figure 6. Photomicrographs of as-received normalized and stress relieved AAR TC128 grade B steel after 30 (a) and 60 (b) minutes at $621 \mathrm{C}$. Etch: 1\% Nital Mag. X500. 

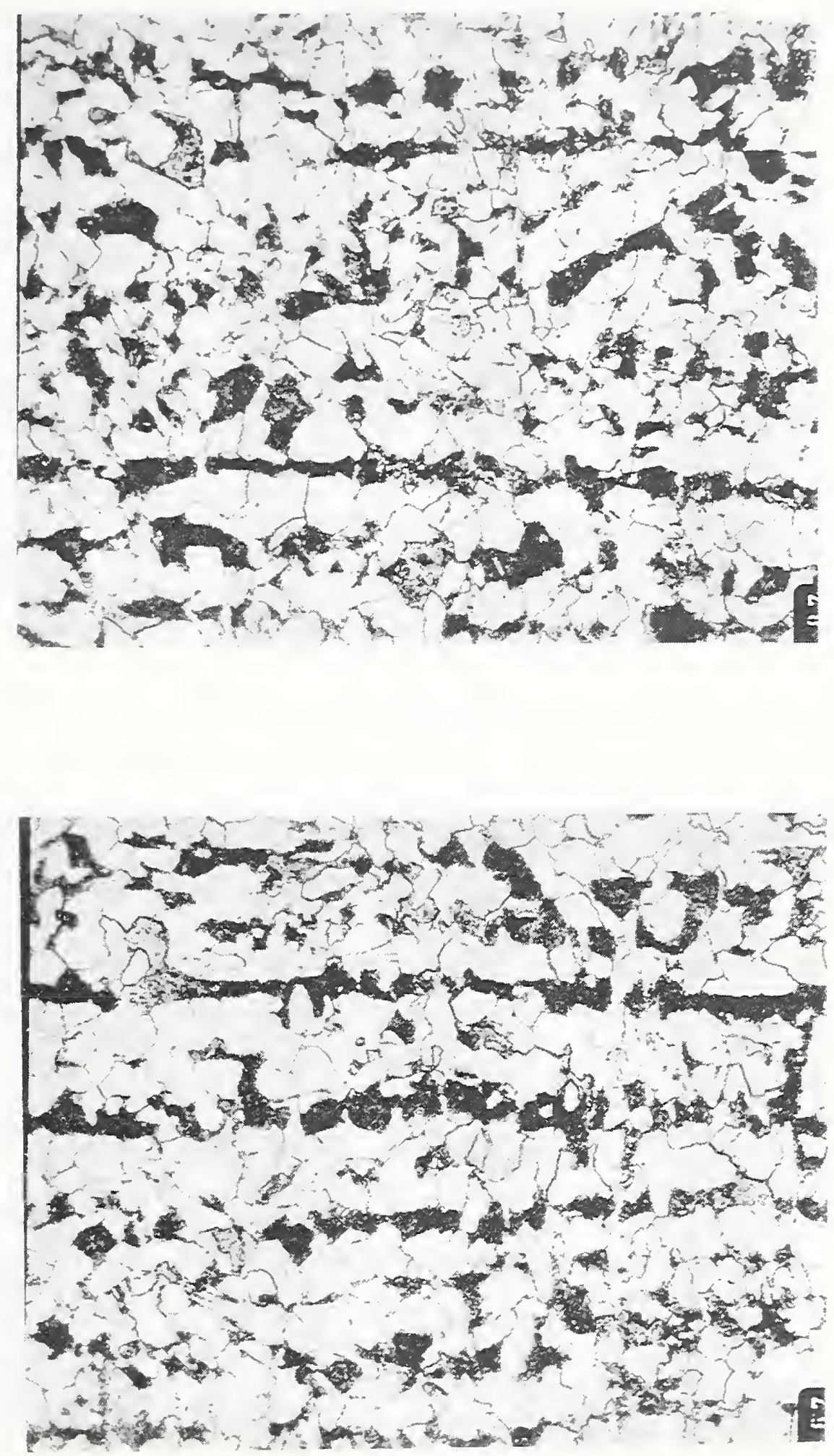

Figure 7. Photomicrographs of as-received normalized and stress relieved AAR TC128 grade B steel after 90 (a) and 120 (b) minutes at $621 \mathrm{C}$. Etch: 1\% Nital Mag. X500. 

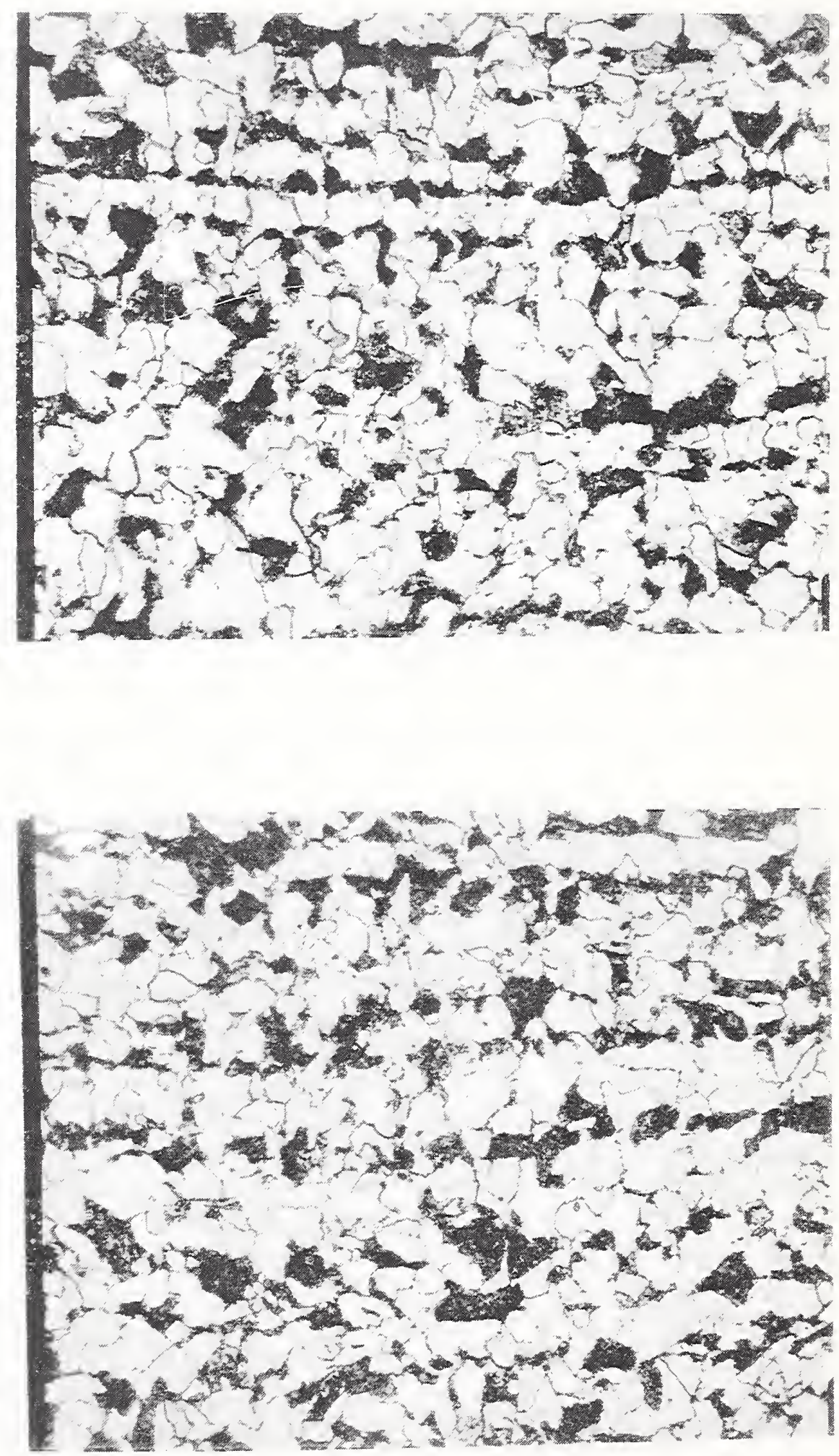

Figure 8. Photomicrographs of as-received normalized and stress relieved AAR TC128 grade B steel after 30 (a) and 60 (b) minutes at $649 \mathrm{C}$. Etch: 1\% Nital Mag. X500. 

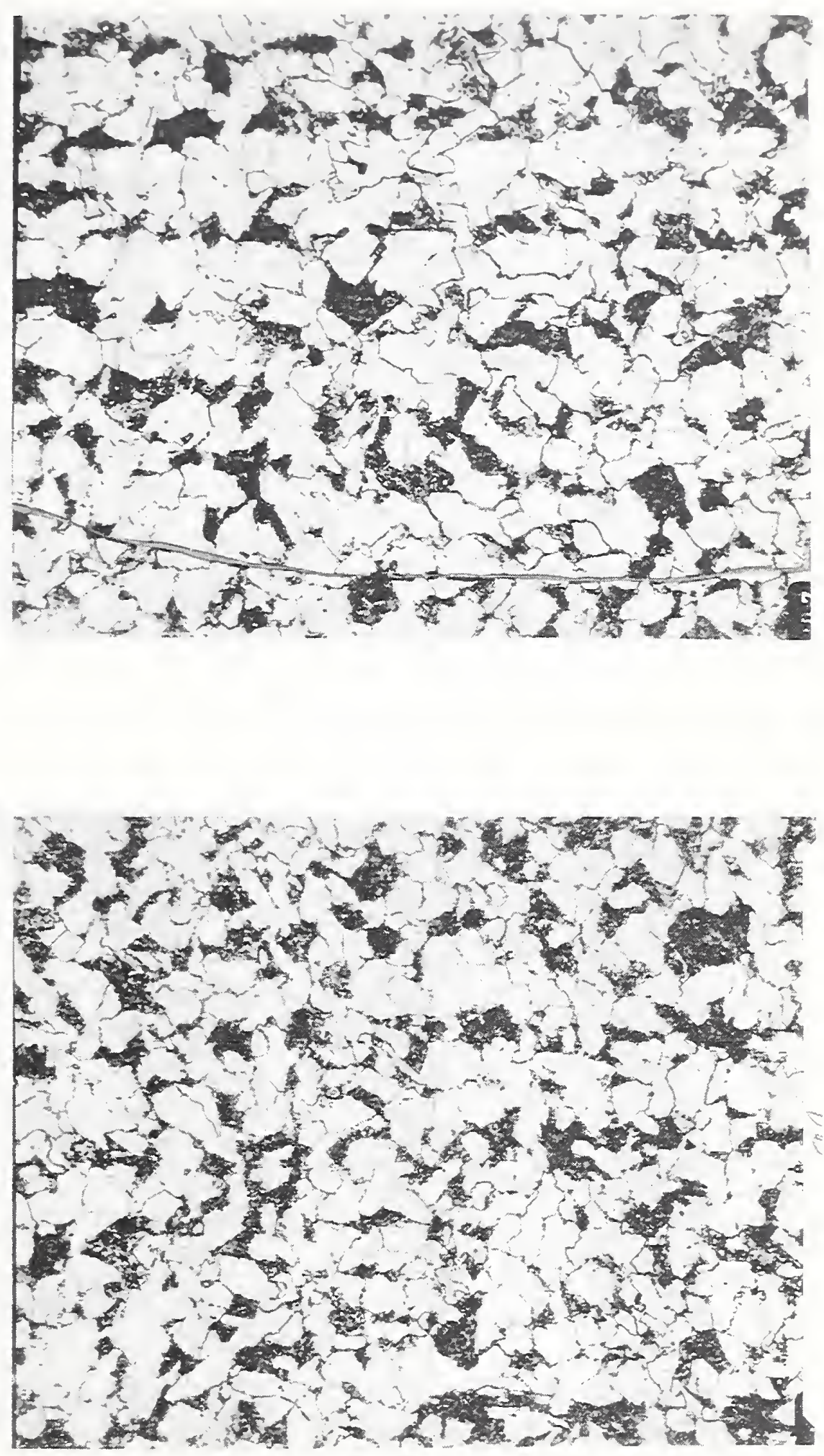

Figure 9. Photomicrographs of as-received normalized and stress relieved AAR TC128 grade B steel after 90 (a) and 120 (b) minutes at $649 \mathrm{C}$. Etch: 1\% Nital Mag. X500. 


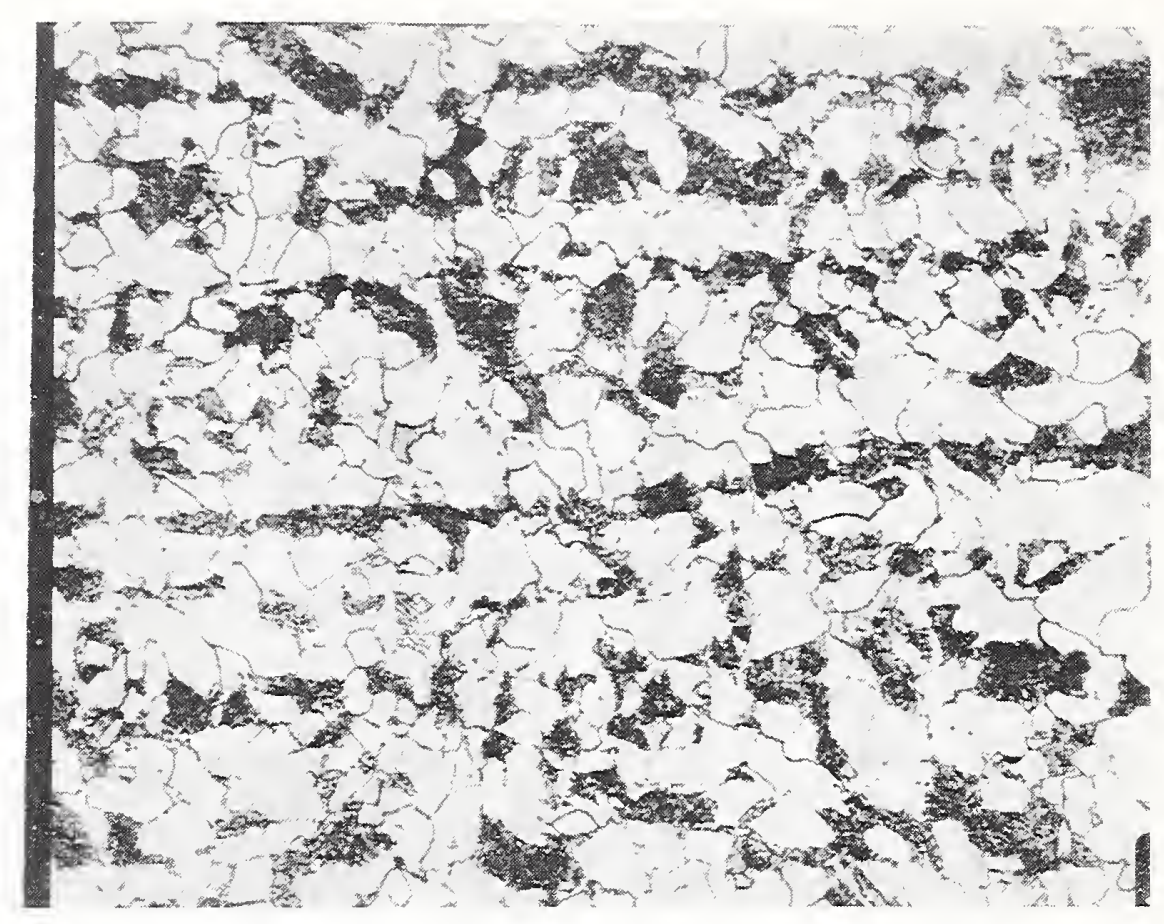

(a)

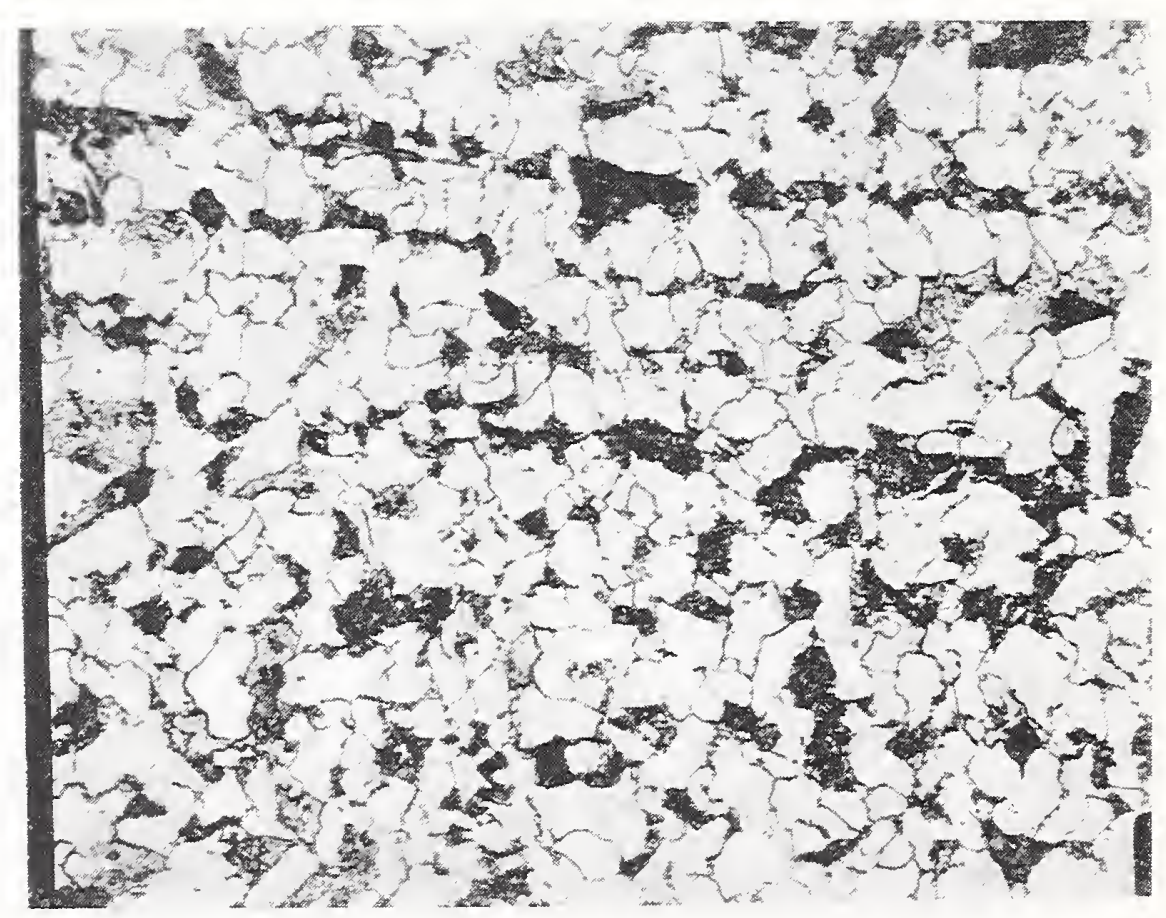

Figure 10. Photomicrographs of as-received normalized and stress relieved AAR TC128 grade B steel after 30 (a) and 60 (b) minutes at $677 \mathrm{C}$. Etch: 1\% Nital Mag. X500. 

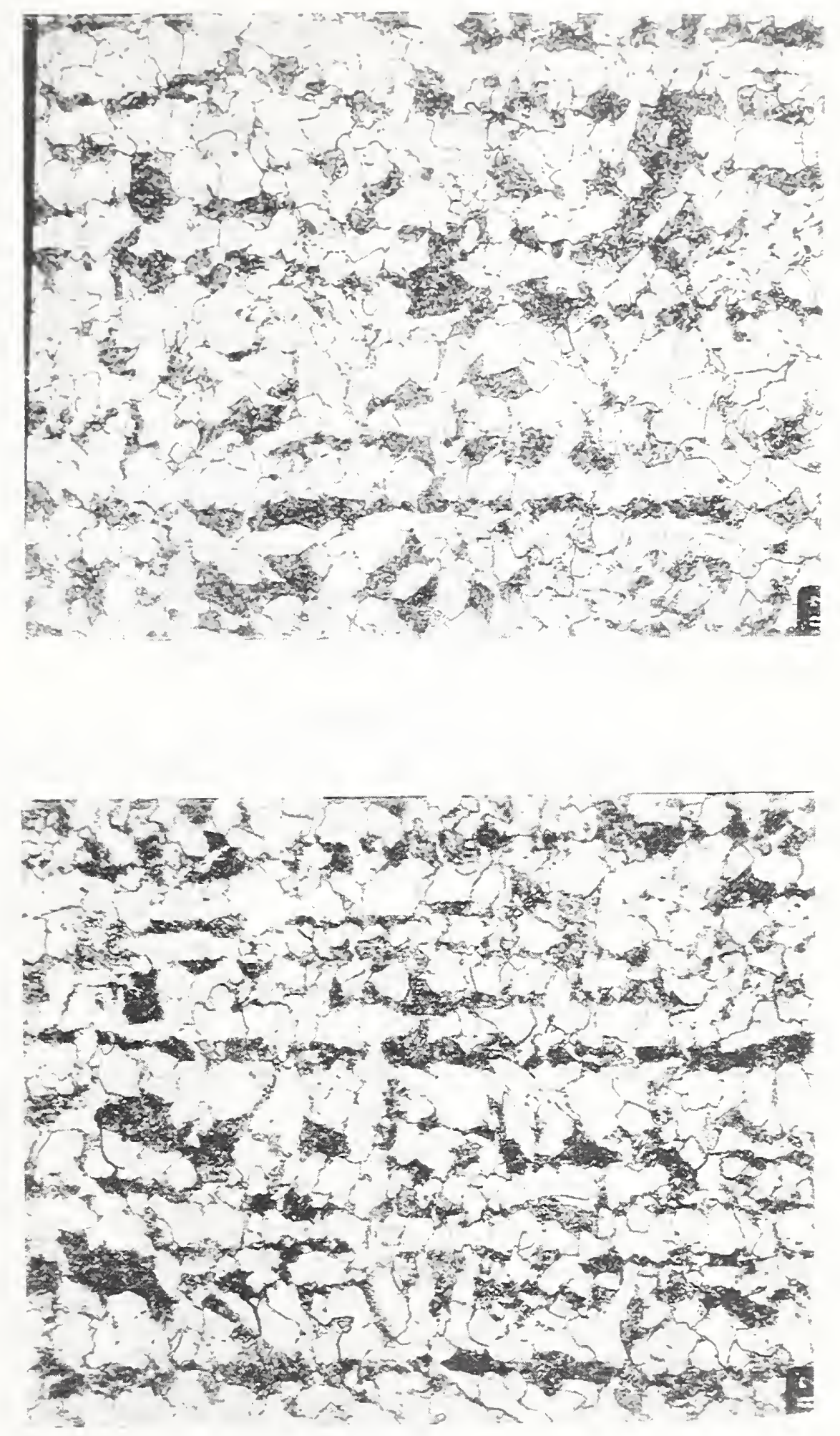

Figure 11. Photomicrographs of as-received normalized and stress relieved AAR TC128 grade B steel after 90 (a) and 120 (b) minutes at $677 \mathrm{C}$. Etch: 1\% Nital Mag. X500. 


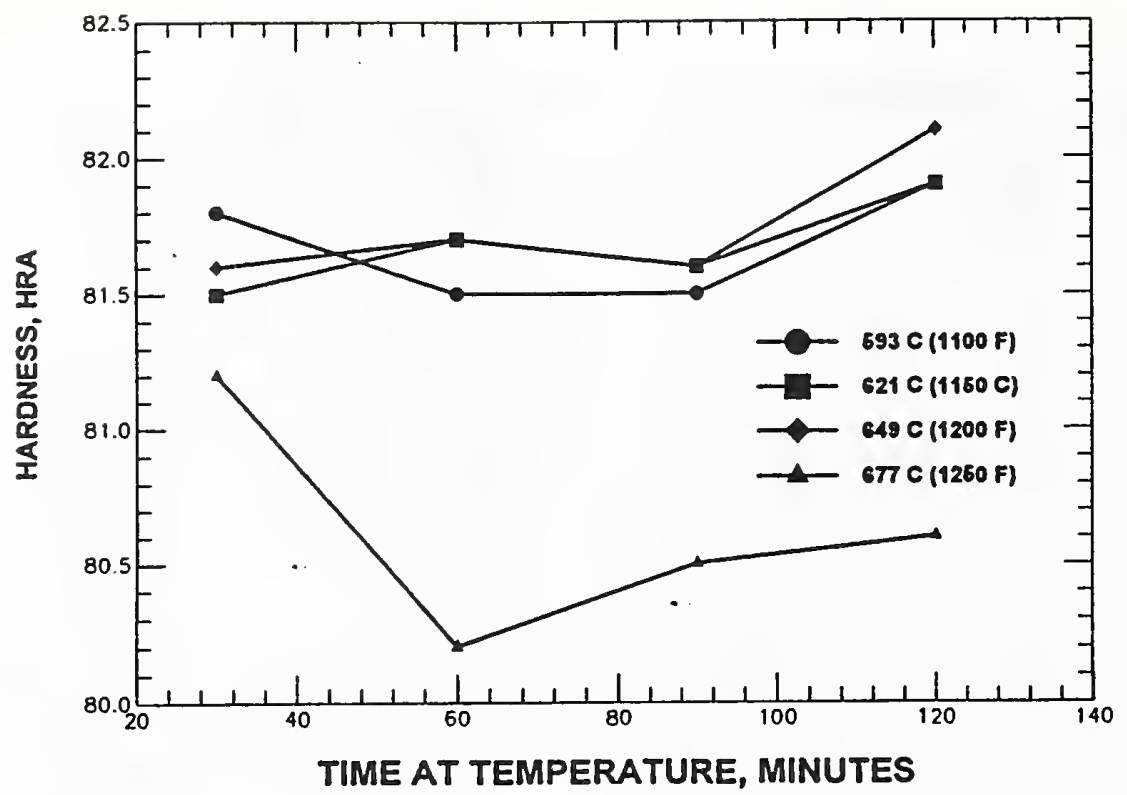

Figure 12. Average hardness (Rockwell A) versus time at $593 \mathrm{C}, 621 \mathrm{C}, 649 \mathrm{C}$, and $677 \mathrm{C}$ for normalized and stress relieved AAR TC128 grade B steel specimens.

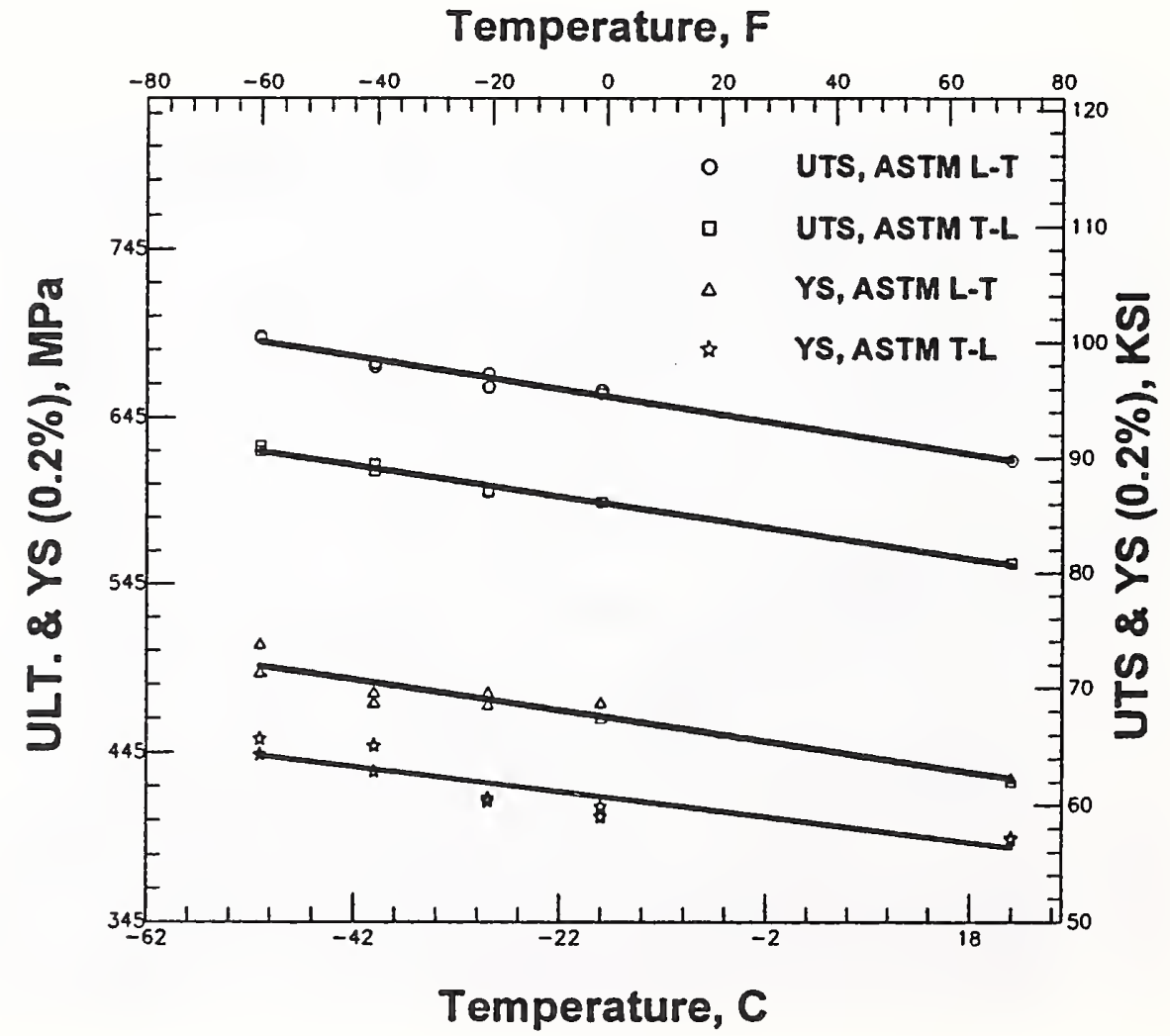

Figure 13. UTS and YS results for normalized and stress relieved AAR TC128 grade $B$ tensile specimens tested at room temperature to $-51 \mathrm{C}$. 


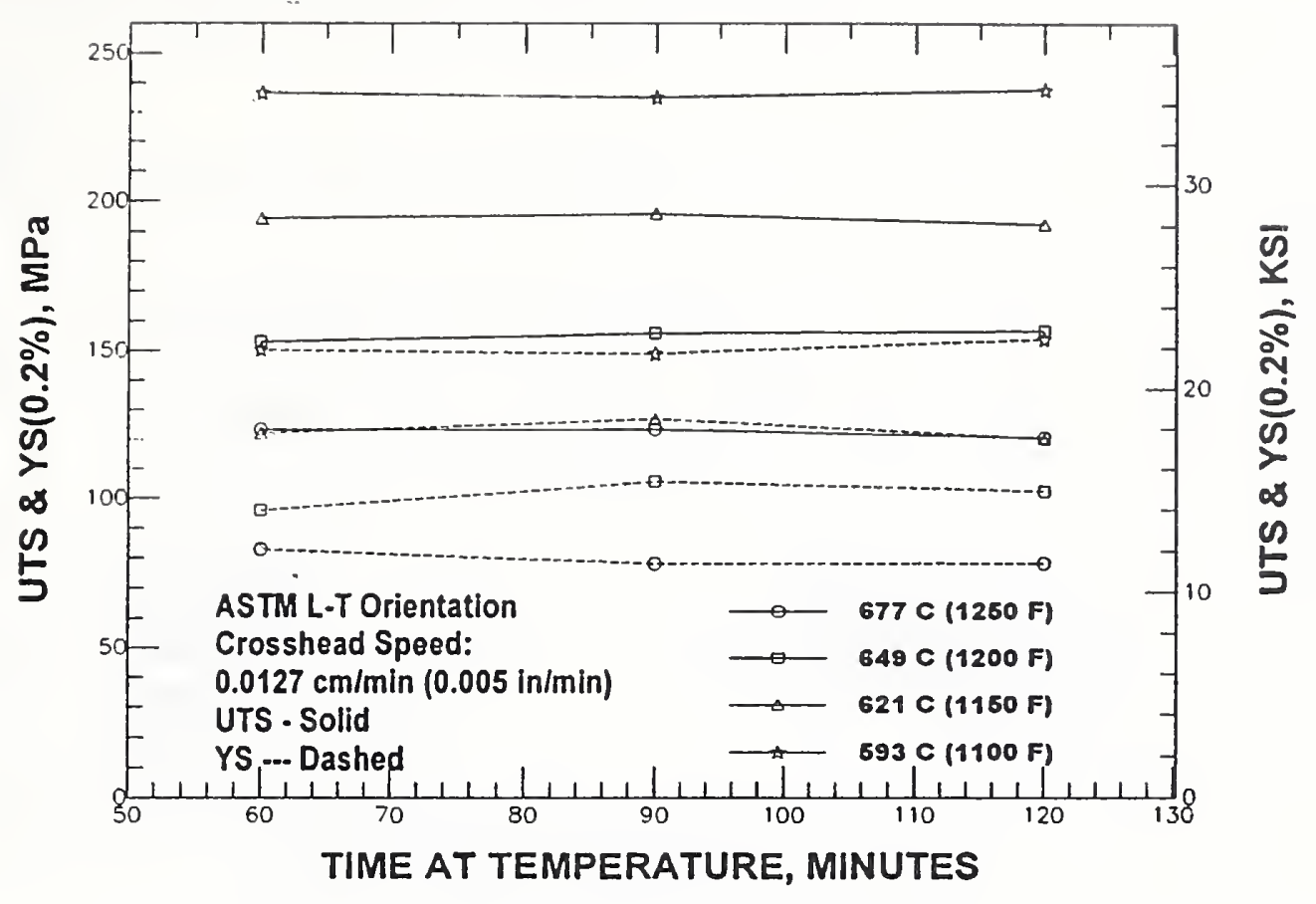

Figure 14. UTS and YS results for specimens tested at a crosshead speed of $0.0127 \mathrm{~cm} / \mathrm{minute}$ and taken from the ASTM L-T direction in the plate.

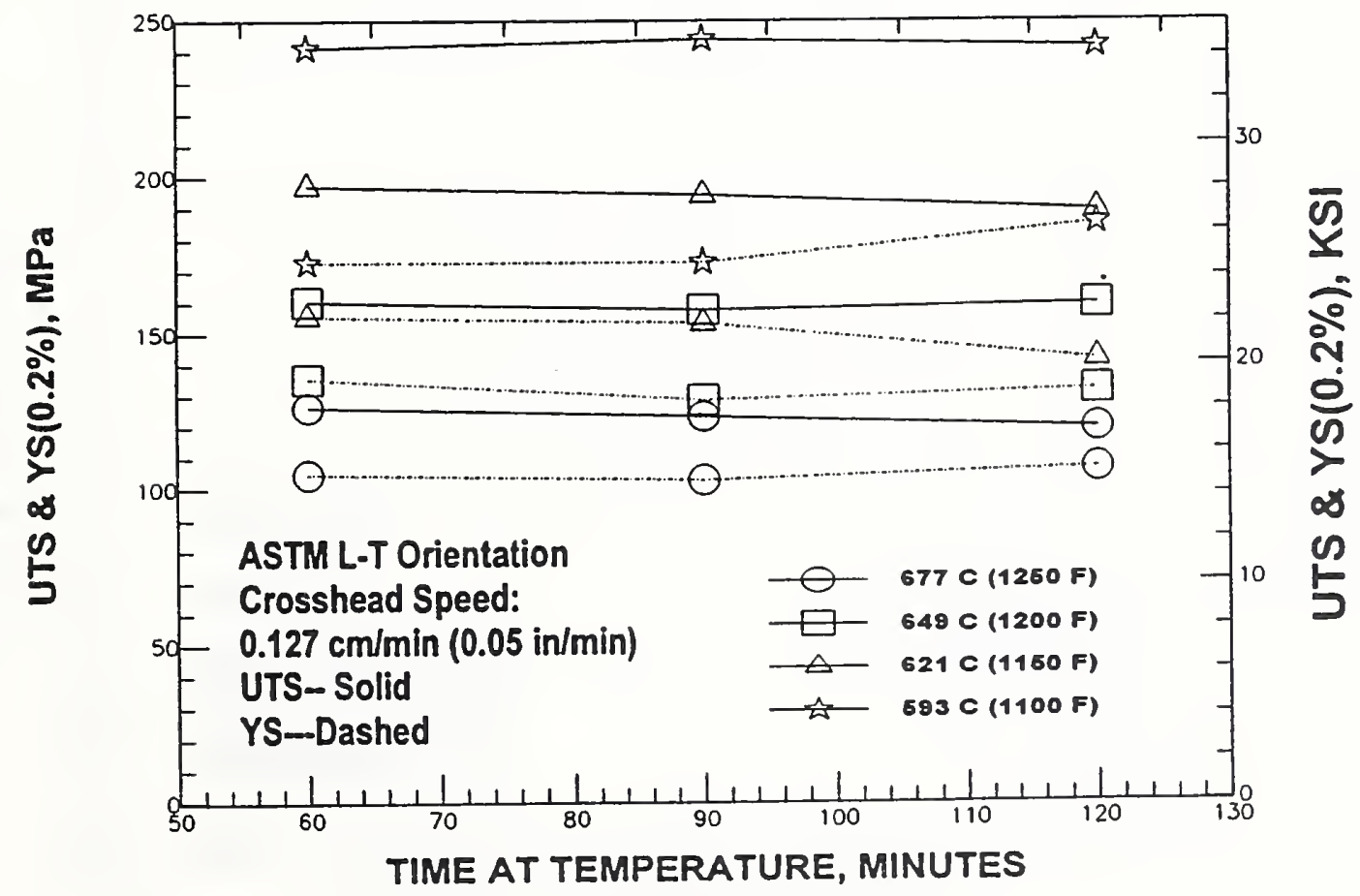

Figure 15. UTS and YS results for specimens tested at a crosshead speed of 0.127 $\mathrm{cm} /$ minute and taken from the ASTM L-T direction in the plate. 


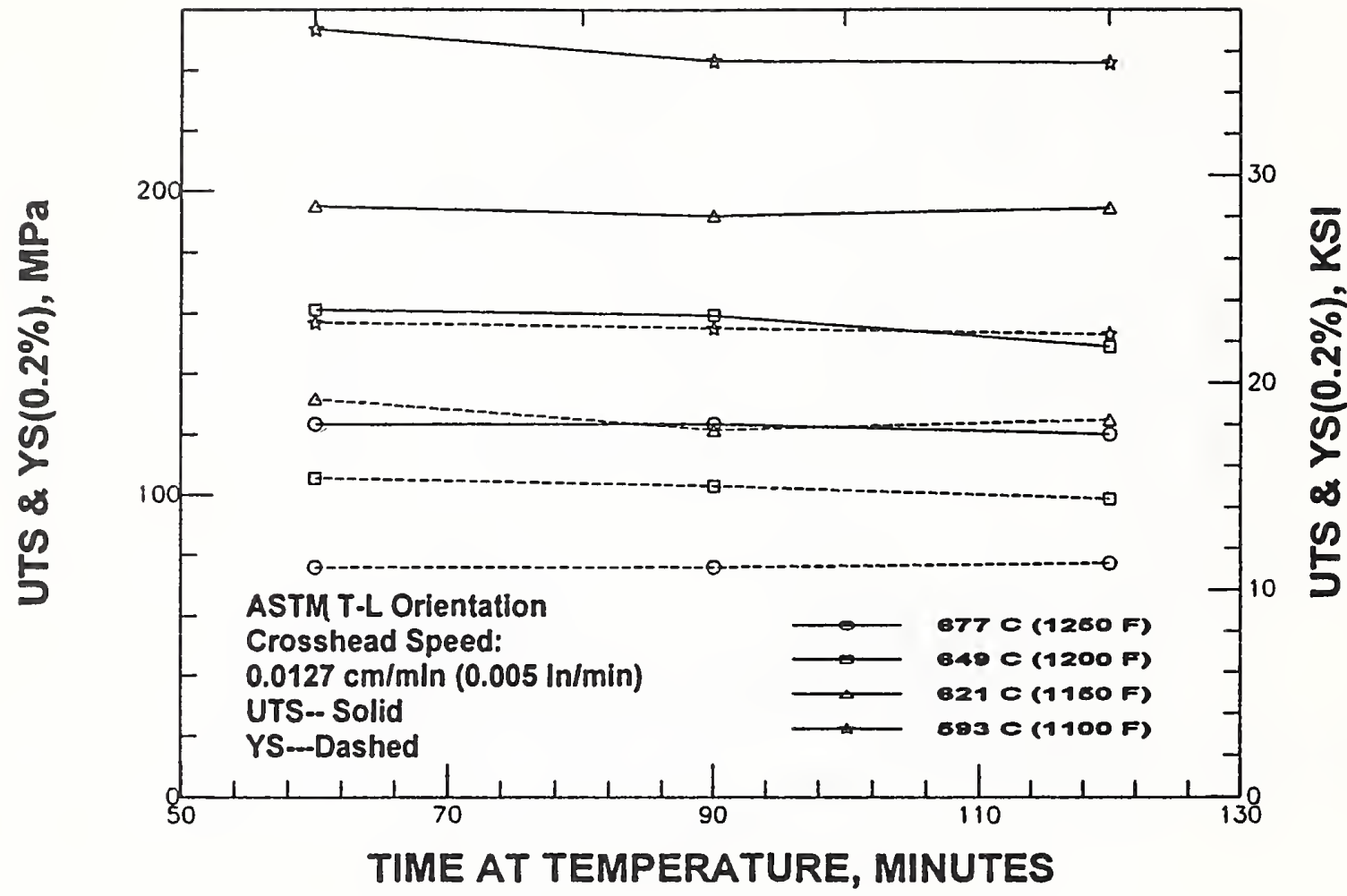

Figure 16. UTS and YS results for specimens tested at a crosshead speed of $0.0127 \mathrm{~cm} /$ minute and taken from the ASTM T-L direction in the plate.

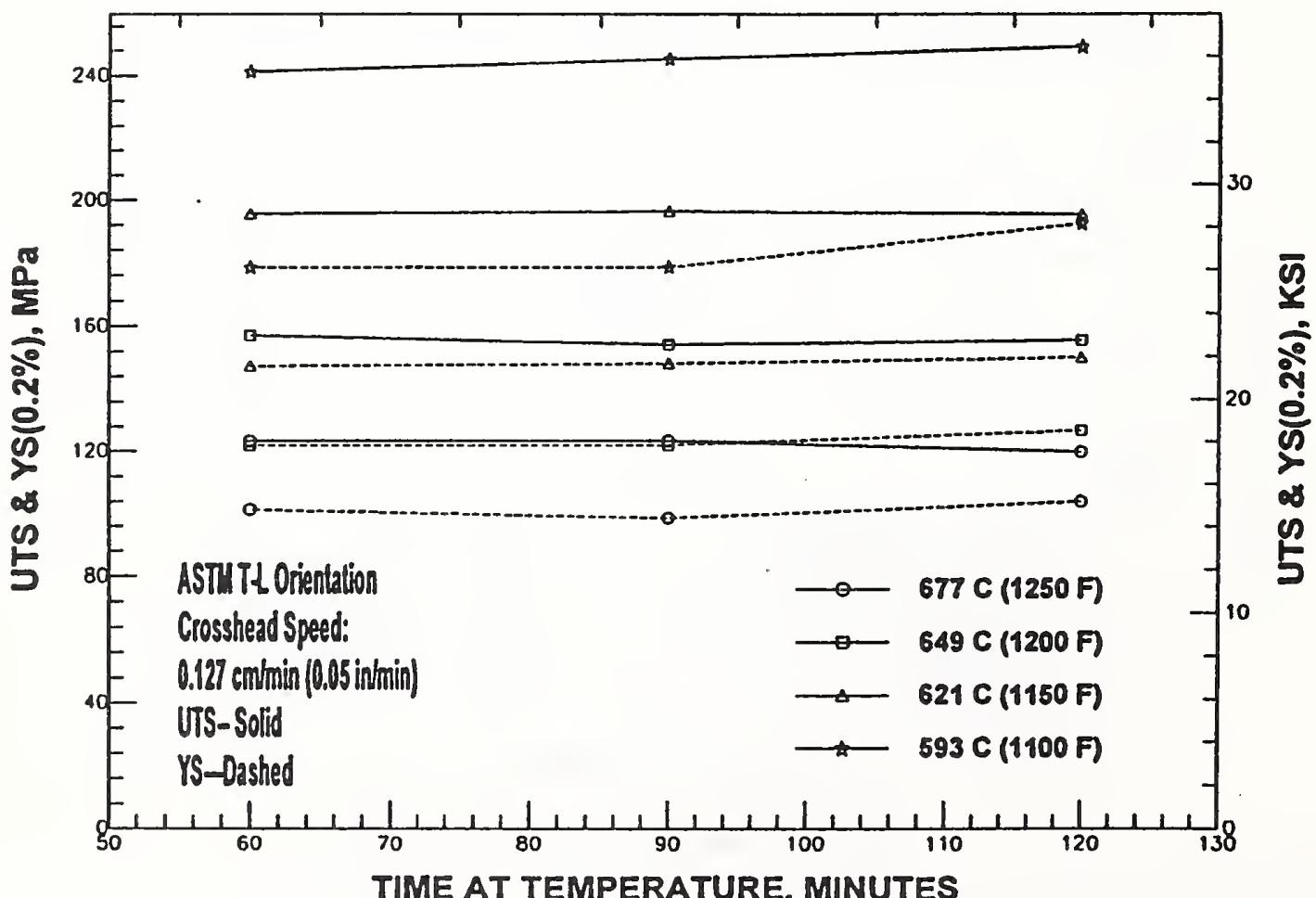

Figure 17. UTS and YS results for specimens tested at a crosshead speed of 0.127 $\mathrm{cm} /$ minute and taken from the ASTM T-L direction in the plate. 


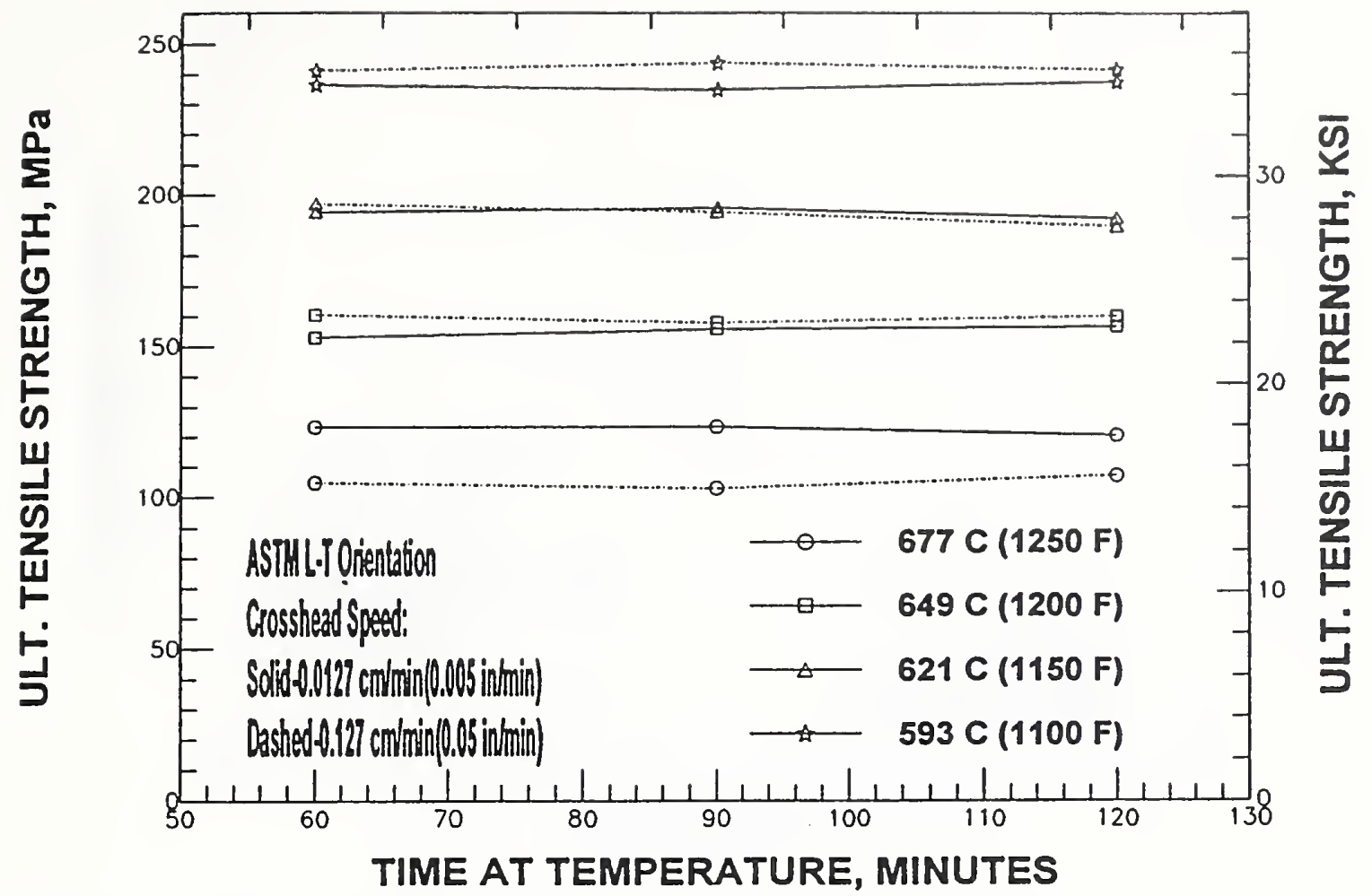

Figure 18. Affects of crosshead speed, temperature, and time on the UTS. Specimens were taken from the ASTM L-T direction in the plate.

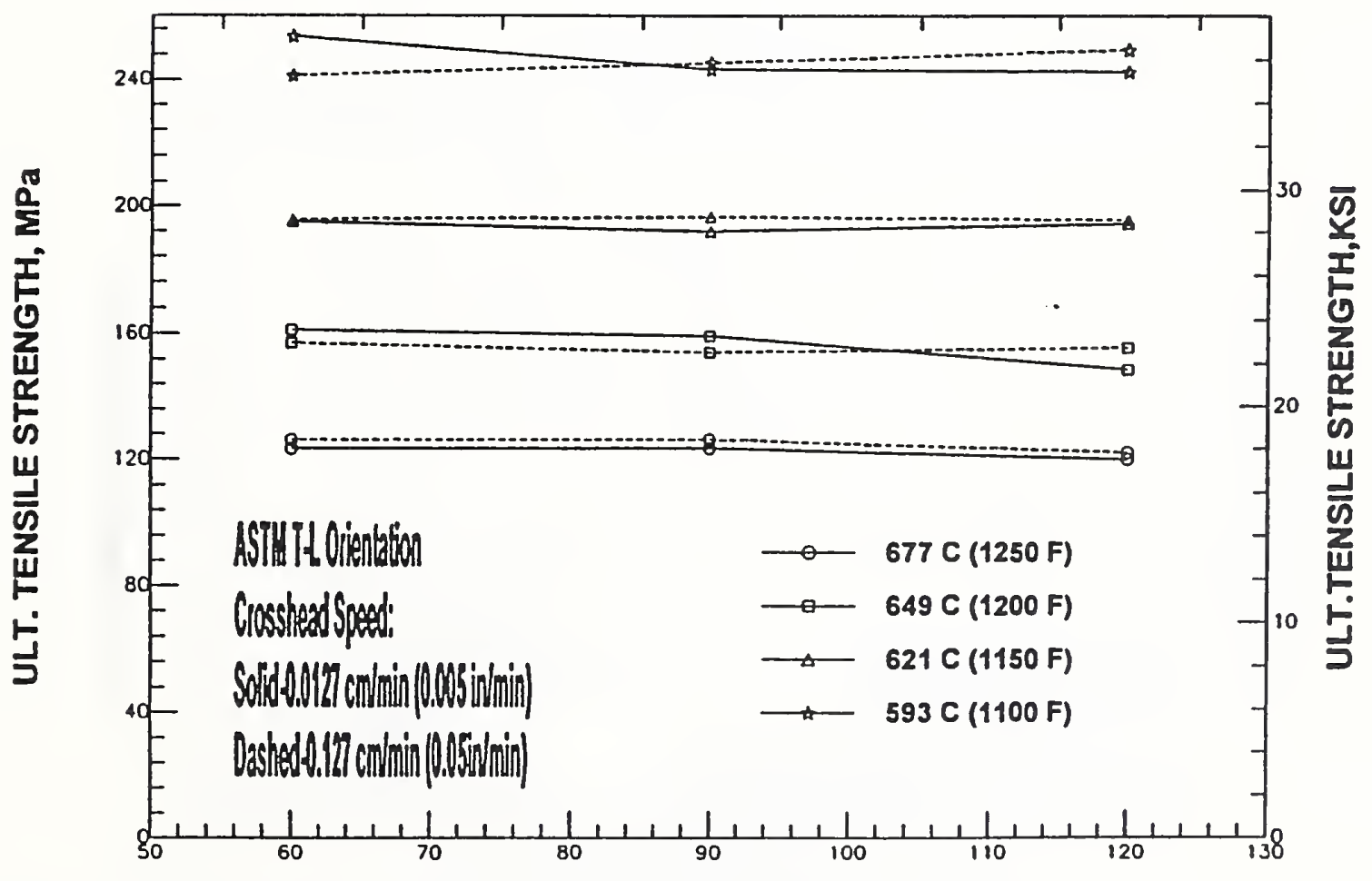

TIME AT TEMPERATURE, MINUTES

Figure 19. Affects of crosshead speed, temperature, and time on the UTS. Specimens were taken from the ASTM T-L direction in the plate. 


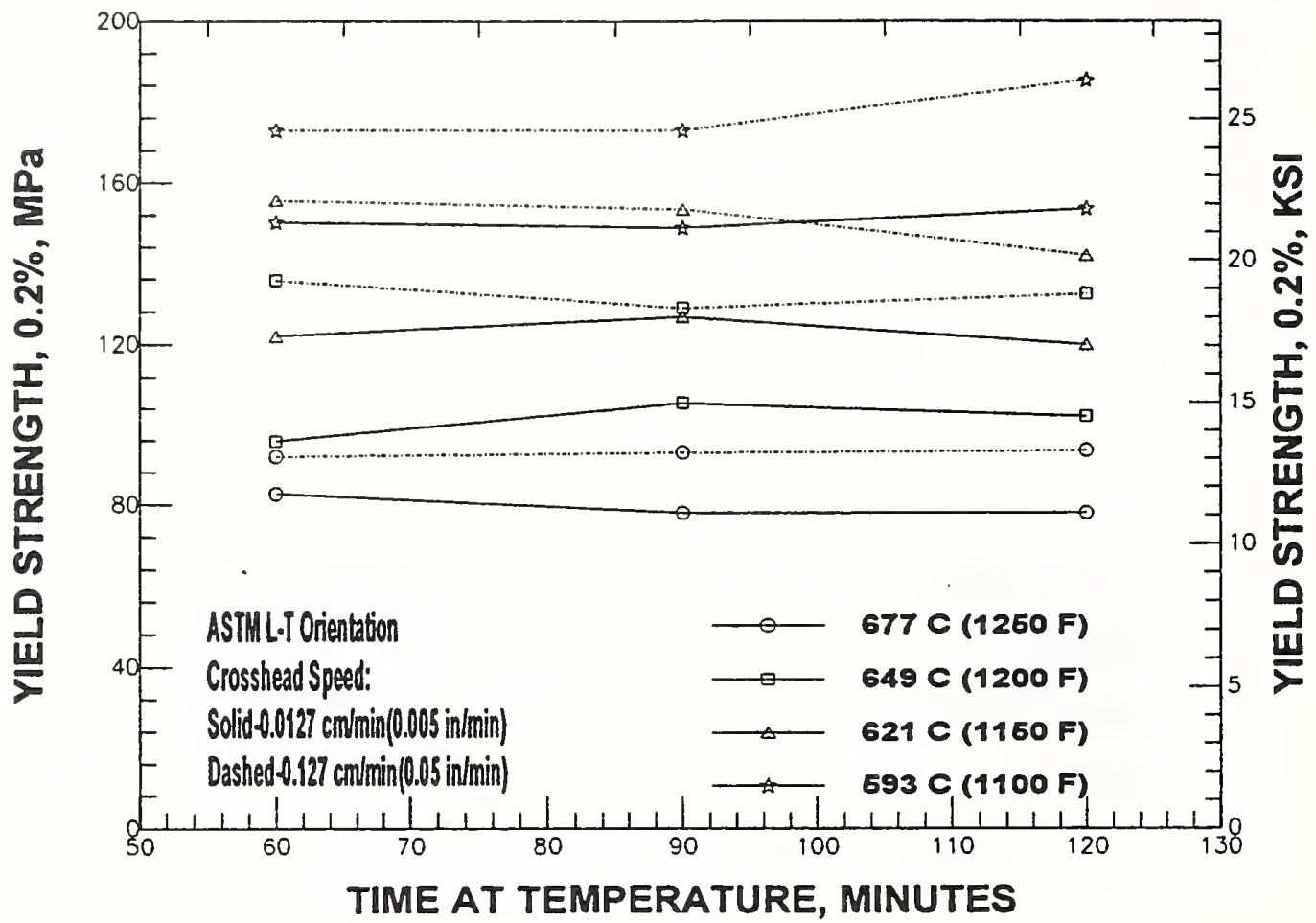

Figure 20. Affects of crosshead speed, temperature, and time on the YS. Specimens were taken from the ASTM L-T direction in the plate.

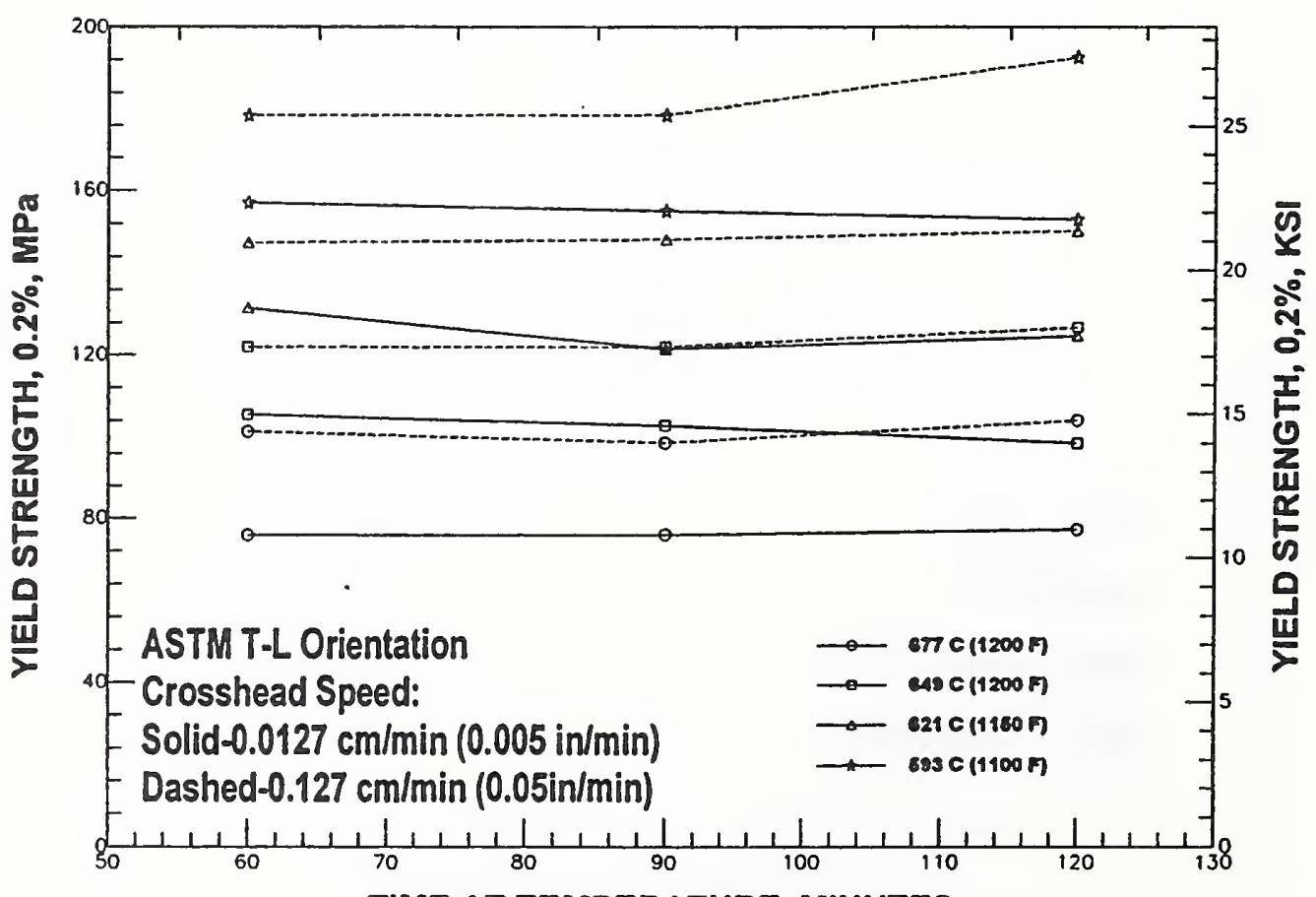

TIME AT TEMPERATURE, MINUTES

Figure 21. Effects of crosshead speed, temperature, and time on the YS. Specimens were taken from the ASTM T-L direction in the plate. 
TEMPERATURE, $F$

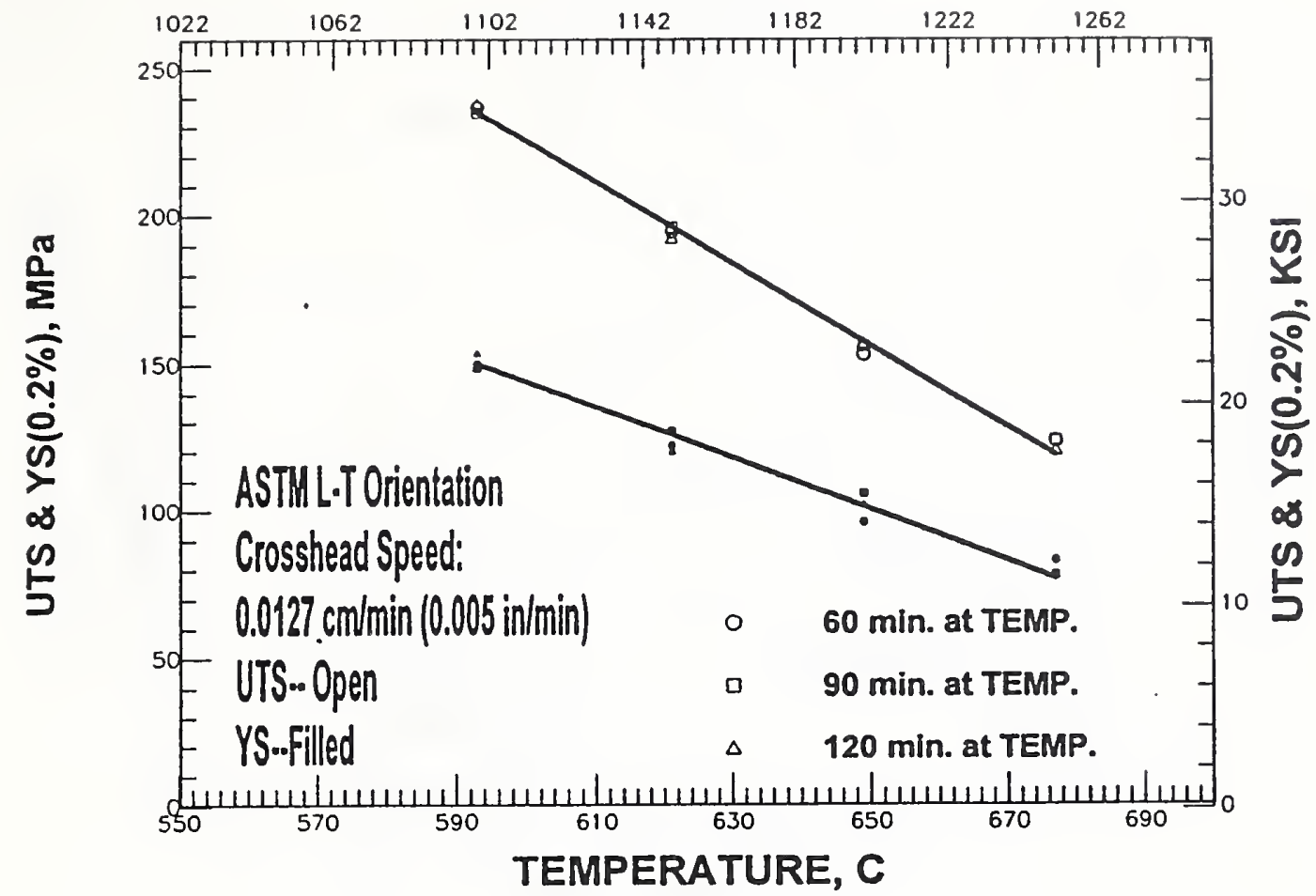

Figure 22. UTS and YS as a function of temperature. Specimens were taken from the ASTM L-T direction in the plate and tested at a crosshead speed of $0.0127 \mathrm{~cm} / \mathrm{minute}$.

TEMPERATURE, $F$

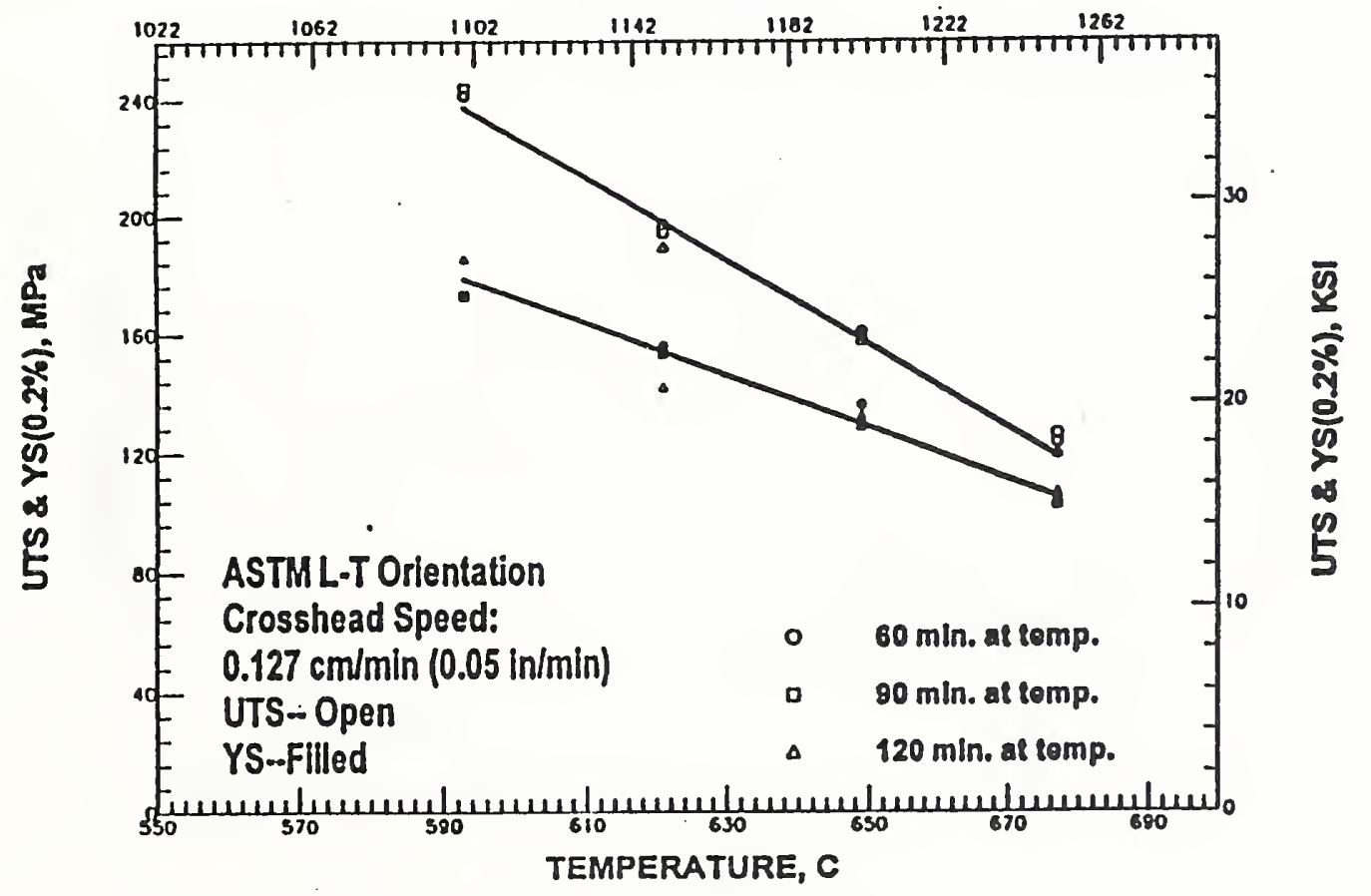

Figure 23. UTS and YS as a function of temperature. Specimens were taken from the ASTM L-T direction in the plate and tested at a crosshead speed of $0.127 \mathrm{~cm} / \mathrm{minute}$. 
TEMPERATURE, $F$

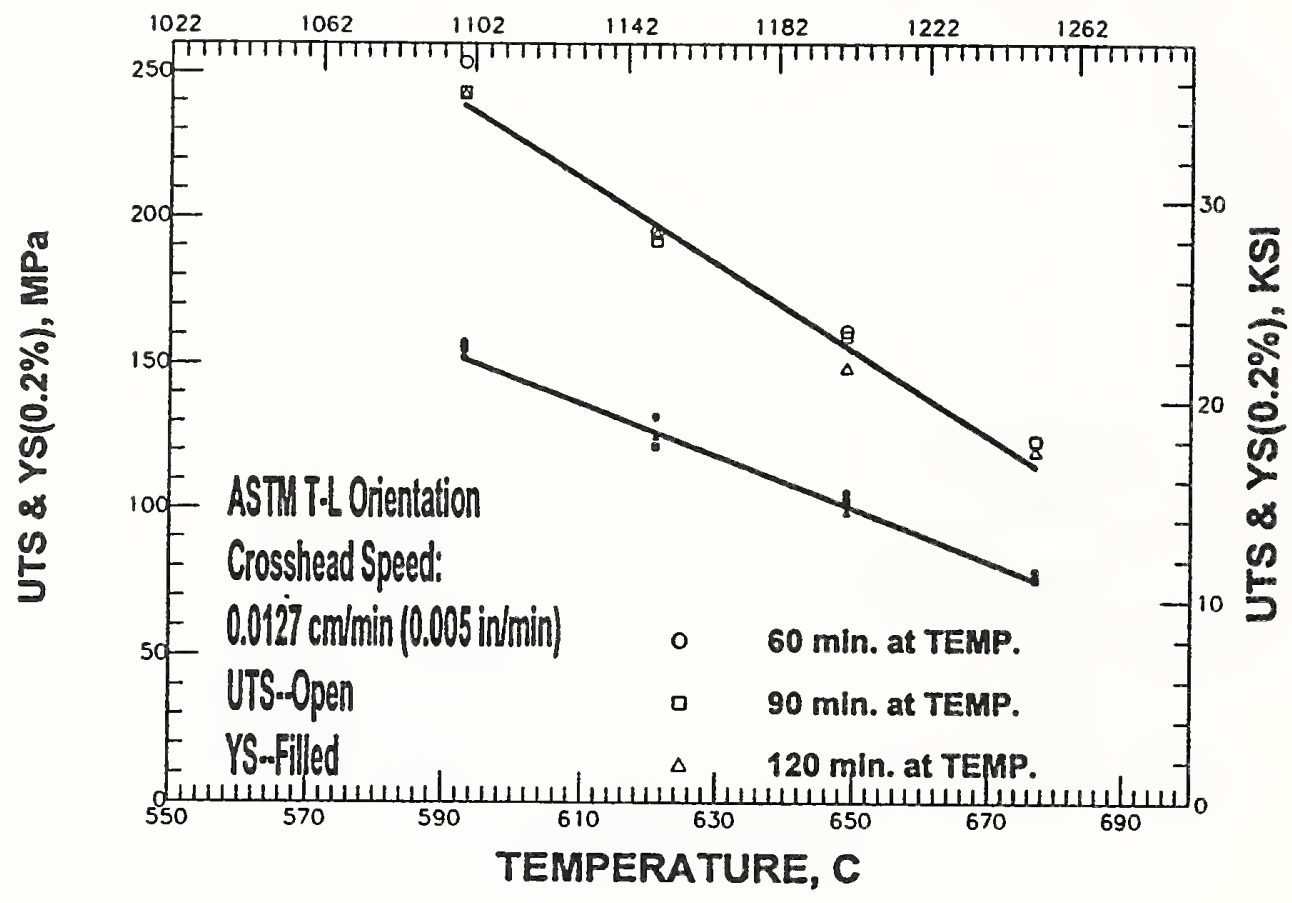

Figure 24. UTS and YS as a function of temperature. Specimens were taken from the ASTM T-L direction in the plate and tested at a crosshead speed of $0.0127 \mathrm{~cm} / \mathrm{minute}$.

TEMPERATURE, $F$

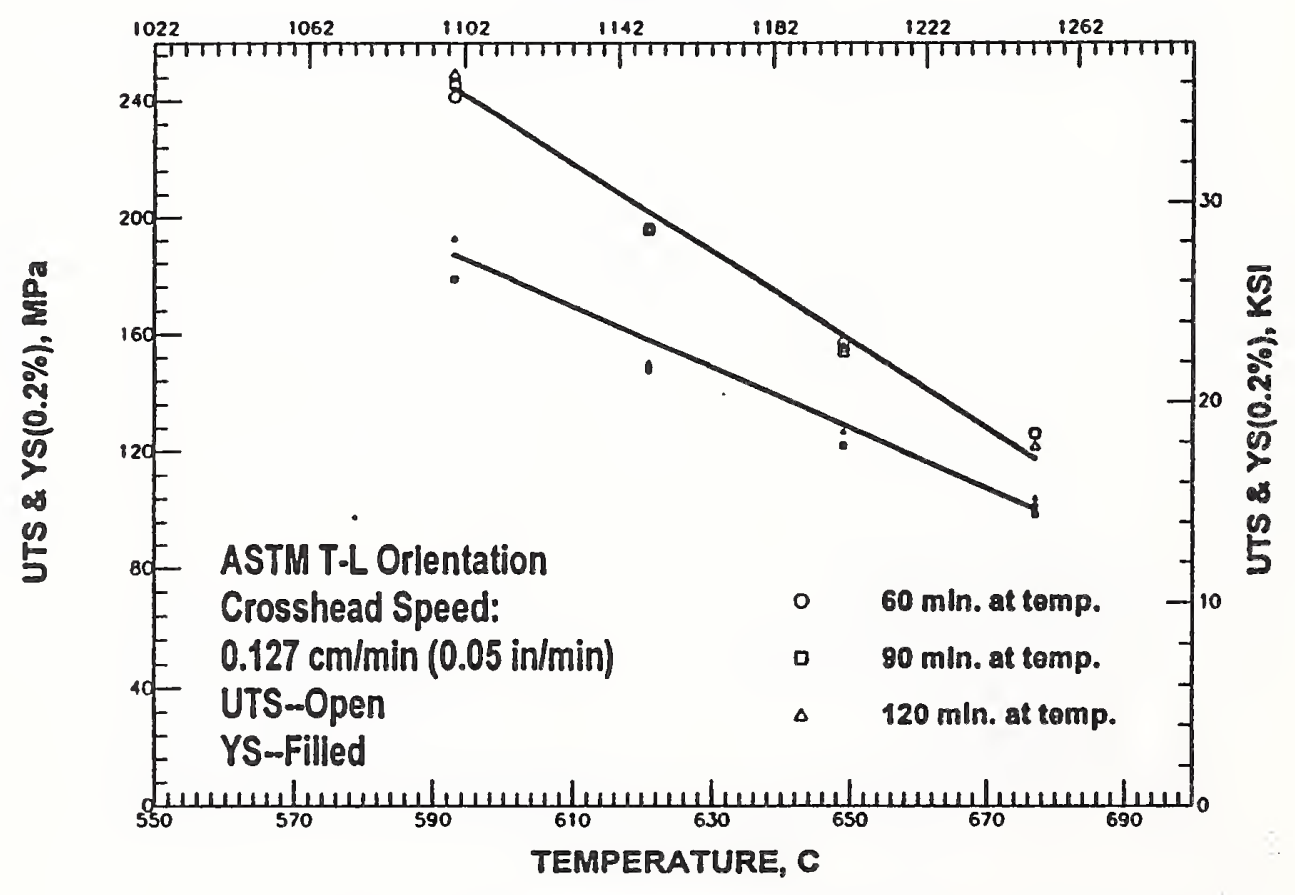

Figure 25. UTS and YS as a function of temperature. Specimens were taken from the ASTM T-L direction in the plate and tested at a crosshead speed of $0.127 \mathrm{~cm} /$ minute. 


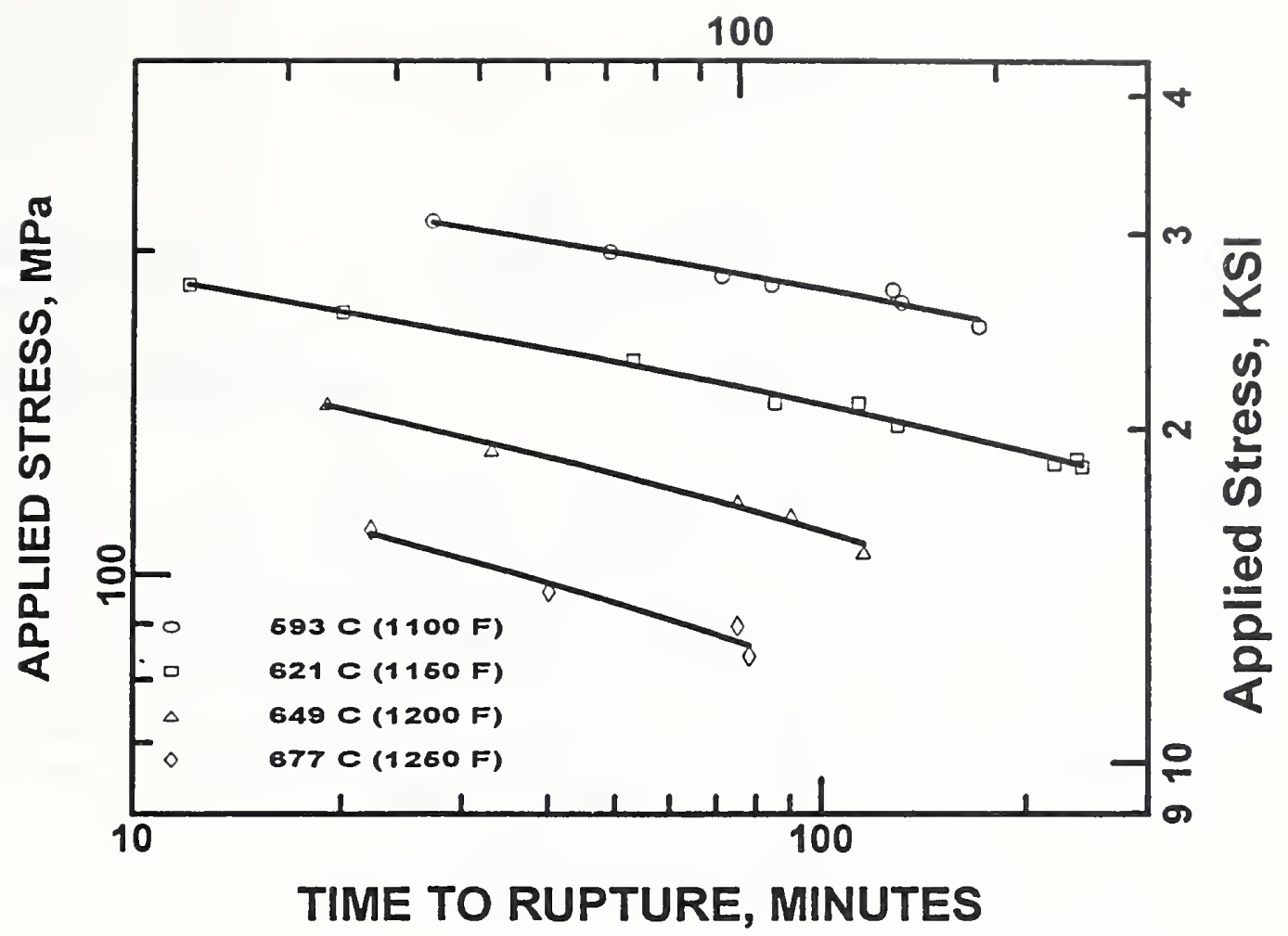

Figure 26. Applied stress versus time to rupture as a function of temperature.

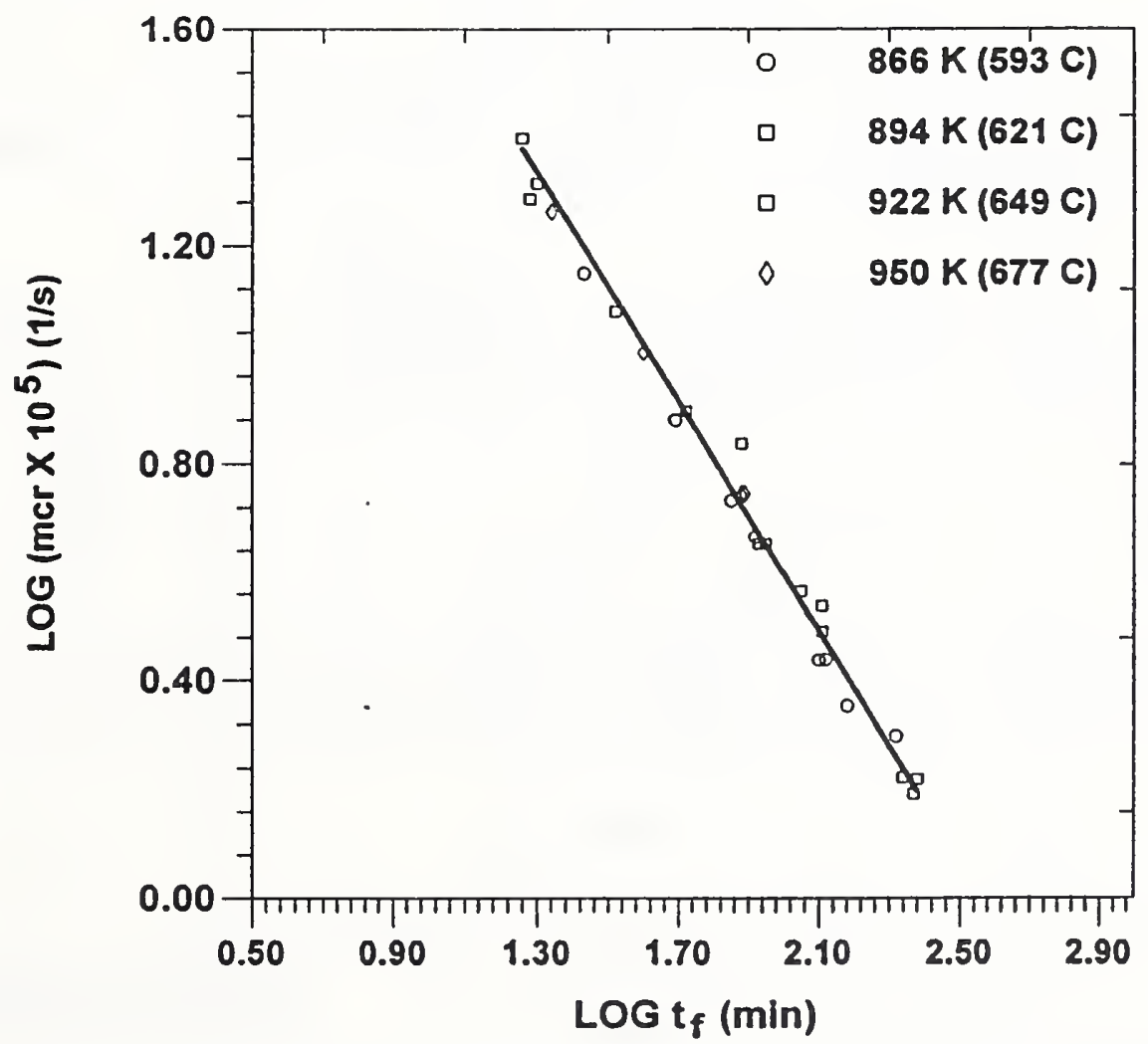

Figure 27. Log of the minimum creep rate versus the $\log$ of the time to failure. 
Appendix I
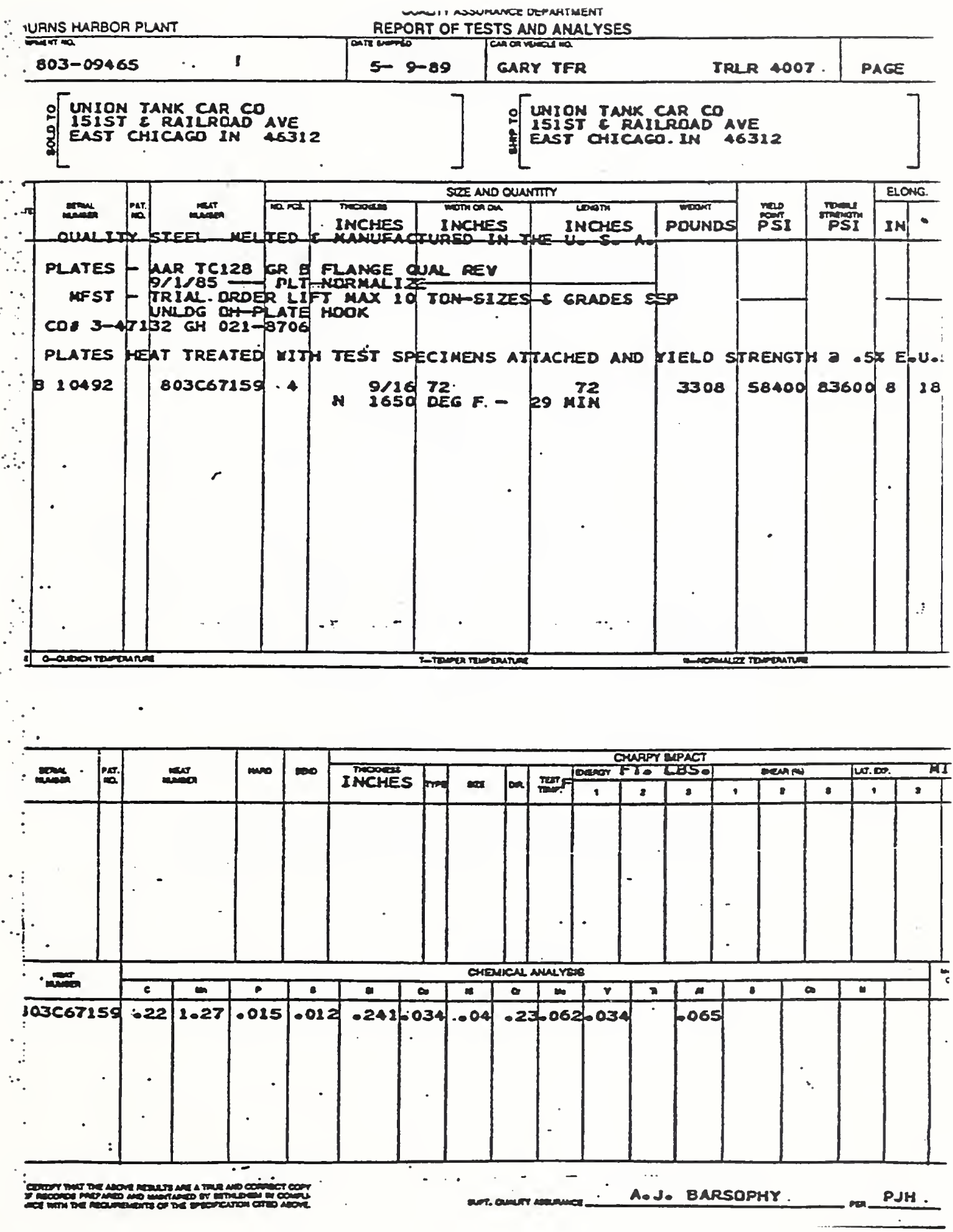
Appendix II

\section{物 E 399}

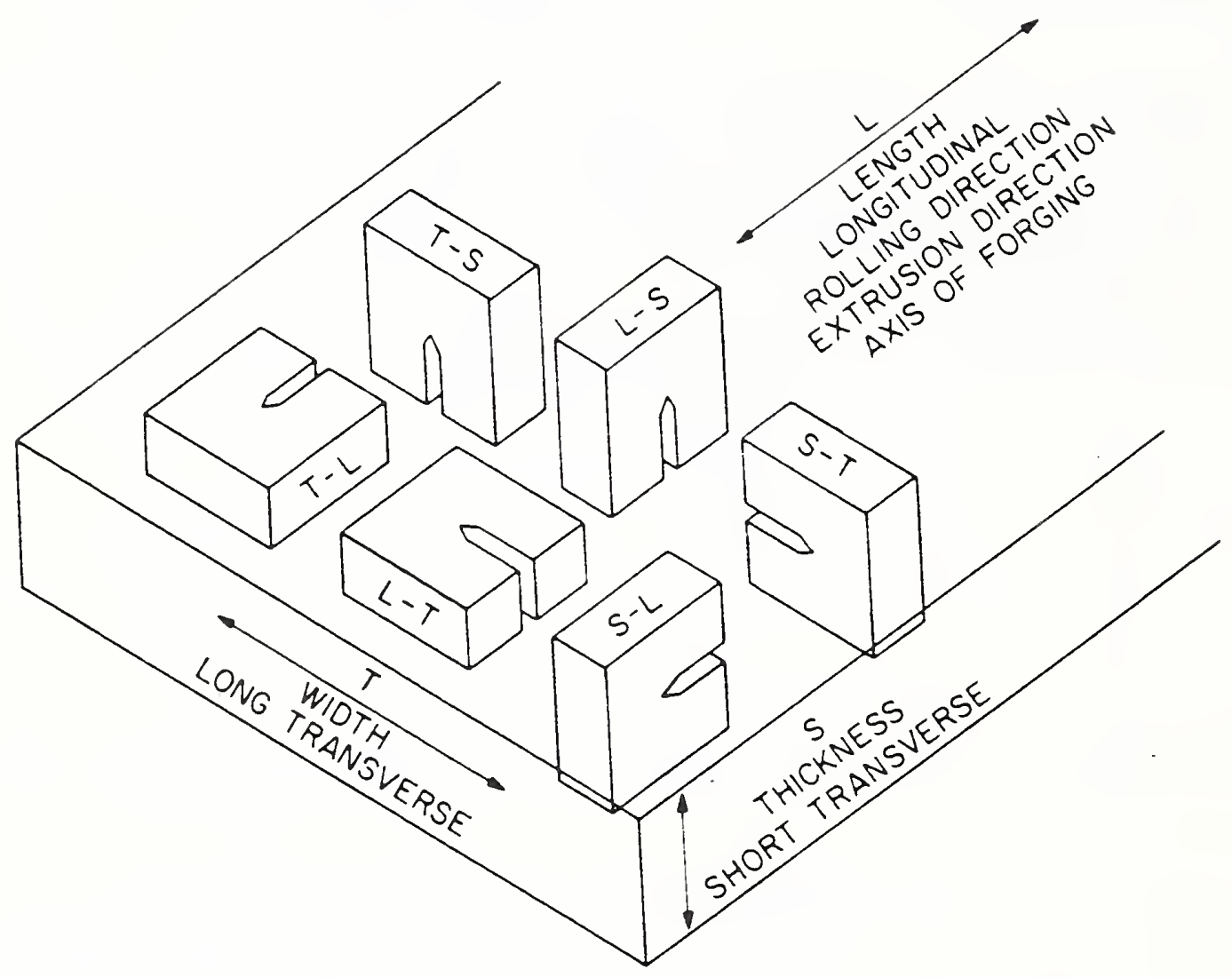

Crack Plane Orientation Code for Rectangular Sections 

